\title{
Biface Knapping Skill in the East African Acheulean: Progressive Trends and Random Walks
}

\section{Shipton (iD)}

Published online: 8 March 2018

(C) The Author(s) 2018. This article is an open access publication

\begin{abstract}
Over the 1.5-million-year duration of the Acheulean, there is considerable variation in biface finesse. It is not clear, however, if there is an improvement in biface knapping ability over time, or if variation between sites is largely unrelated to their age. The diversity and duration of the East African Acheulean presents an opportunity to examine this issue. Variables that reflect difficult aspects of biface knapping, and which were likely important goals for Acheulean hominins, were measured in order to assess skill. These variables - refinement (thinness), edge straightness, and symmetrywere compared across four East African Acheulean sites: Olduvai Gorge, Olorgesailie, Kariandusi, and Isinya. The influence of rock type, blank type, reduction intensity, aberrant scar terminations, and invasive flaking on these variables was assessed. Over relatively short timescales, confounding factors, including ones not possible to control for, tend to obscure any temporal signature in biface knapping skill. However, over the vast timespan of the
\end{abstract}

Electronic supplementary material The online version of this article (https://doi.org/10.1007/s10437-018-9287-1) contains supplementary material, which is available to authorized users.

C. Shipton $(\bowtie)$

McDonald Institute for Archaeological Research, University of Cambridge, Cambridge, UK

e-mail: ceri.shipton@anu.edu.au

\section{Shipton}

British Institute in Eastern Africa, Nairobi, Kenya

C. Shipton

Centre of Excellence for Australian Biodiversity and Heritage, Australian National University, Canberra, Australia
Acheulean at Olduvai Gorge, a temporal trend was indeed apparent. Possible factors influencing this trend include the invention of new knapping techniques, the addition of adolescence as a life history stage, and evolving hominin cognition.

Résumé Au cours de la durée de 1.5 million d'années de l'Acheuléen, il existe une variation considérable de la finesse biface. Cependant, il n'est pas clair s'il existe une amélioration de la capacité de taille en biface dans le temps, ou si la variation entre les sites est en grande partie sans lien avec leur âge. La diversité et la durée de l'Acheuléen de l'Afrique de l'Est sont l'occasion d'examiner cette question. Des variables qui reflètent des aspects difficiles du taille biface, susceptibles d'être importants pour les hominins Acheuléen, ont été mesurées afin d'évaluer les compétences. Ces variables étaient le raffinement (minceur), la rectitude du bord, et la symétrie, et ont été comparées dans quatre sites Acheuléen de l'Afrique de l'Est: gorges d'Olduvai, Olorgesailie, Kariandusi, et Isinya. L'influence du type de roche, du type support, de l'intensité de réduction, des terminaisons de éclat aberrantes et des écailles invasives sur ces variables a été évaluée. Sur des échelles de temps relativement courtes, les nombreux facteurs qui affectent les formes de bifaces tendent à masquer toute signature temporelle dans la compétence de biface knapping. Cependant, sur le vaste laps de temps de l'Acheuléen sur des sites comme Olduvai Gorge, une tendance temporelle est en effet évidente. Parmi les facteurs qui peuvent influencer cette tendance, on peut citer l'invention de nouvelles techniques de taille, l'ajout 
de l'adolescence comme stade de l'histoire de la vie et l'évolution de la cognition de l'hominine.

Keywords Olduvai Gorge · Handaxe · Cleaver . Refinement $\cdot$ Symmetry $\cdot$ Edge straightness

\section{Introduction}

For nearly 150 years, scholars of the Acheulean have speculated that there may be chronological patterns within the period (de Mortillet 1873), but the issue remains controversial (McNabb and Cole 2015). East Africa is the original homeland of the Acheulean with the earliest sites documented c. 1.75 million years ago (mya) at Konso in the southern Ethiopian Highlands, Kokiselei on the west side of Lake Turkana, and at Olduvai Gorge to the southeast of Lake Victoria (Beyene et al. 2013; Diez-Martín et al. 2014; Lepre et al. 2011). The Acheulean in East Africa persists until at least c. 0.2 mya (Benito-Calvo et al. 2014; McKinney 2001; Tryon and McBrearty 2006) when it is succeeded by the Middle Stone Age. East Africa thus presents an excellent opportunity to examine temporal trends in the period. The longue dureé perspective on the Acheulean is epitomised by Olduvai Gorge where successive layers of Acheulean occupation can be found spanning 1.75 to 0.4 mya (McHenry 2005; McHenry et al. 2008; Tamrat et al. 1995). In fact, in Louis Leakey's (1951) original study of the Olduvai Gorge bifaces, he divided them into no less than 11 progressive stages (Fig. 1): "The culture sequence - from the base of the deposits of Bed I to the top of Bed IV - reveals a slow and gradual evolution from the simple pebble tools of the Oldowan to the most beautifully made small hand-axes and cleavers of the Late Acheulean type" (Leakey 1951, p. 158).

Each of Leakey's original stages had distinctive technological features, such as Stage 2 with its large handaxes with thick butt-ends and plano-convex profiles, or Stage 7 with its frequent use of a soft hammer, the presence of cleavers, and large well-made bifaces (Leakey 1951).

Stratigraphic revisions were made to the Olduvai sequence following Leakey's preliminary publication. The relative ages of assemblages within beds were altered from their original positioning, leading Louis and Mary Leakey to reject the fine progression schema (L. Leakey et al. 1965; M. Leakey 1967, 1971). Individual examples of well-made bifaces occur in early assemblages at Olduvai Gorge (Diez-Martín et al. 2014), and poorly made examples occur in later assemblages. With the revision of Louis Leakey's fine progression, Glynn Isaac's (1971) random walk model came to the fore, in which progressive signatures in bifaces are largely obscured by the range of variation between sites of similar age: "What do numbered stage divisions such as those formerly employed in the Somme, Morocco or Olduvai mean if a penecontemporaneous set shows almost as much diversity as a markedly diachronic series?" (Isaac 1971, p. 173).

Isaac (1971) observed that in variables such as biface length, elongation, and thinness, the variation between individual localities at Olorgesailie, Isimila, and Kalambo Falls exceeded the variation between these broad sites of different ages. His random walk model proposed that due to the influence and interaction of traditions, functional requirements, and raw materials, any time trends in Acheulean biface skill would be extremely weak. This characterisation of intra-assemblage variability exceeding much inter-assemblage variability also holds up in multivariate analyses of several linear dimensions on bifaces (Gowlett 2015). Isaac (1971, p. 184) did see weak trends for increasing refinement at Olorgesailie, but he noted that "there is room for a great deal of random oscillation within a general drift of change that lasted almost a million years." In his more recent study of the Olduvai Gorge bifaces, Roe (1994) saw that there were general trends from the vast timespan covered between Bed II and post-Bed IV, but emphasised that these were local trends and there was substantial variation within each bed.

The perception that there is progression through time in the Acheulean more generally is widespread (Clark 1994; Gaillard et al. 1986; Hodgson 2015; Misra 1978; Paddayya 2007; Sahnouni et al. 2013; Schick and Clark 2003), though not often formally tested. Earlier Acheulean bifaces are characterised as being relatively asymmetrical, with thick cross-sections, and wavy sinusoidal profiles, while late Acheulean forms are described as thinner, more symmetrical, and with straighter edges (Fig. 1) (Clark 1999, 2001; Roe 1994; Wynn 2002).

Experimental knappers note the high skill levels required to replicate the finer examples of Acheulean bifaces (Bradley and Sampson 1986; Edwards 2001; Newcomer 1971; Winton 2005). Geribàs et al. (2010) identify the type of percussion support, the position of the blank, and the angle of the blow as three gestures that must be mastered for handaxe knappers to become experts. Other studies highlight the need for hierarchical organisation, in which knapping proceeds in stages 
Fig. 1 Four Acheulean handaxes from Olduvai Gorge used in this study and also selected by Leakey to represent his evolutionary stages (after Leakey 1951). The top left specimen is from the bottom of Bed II, the top right from the middle of Bed II, the bottom left from Bed III and the bottom right from Bed IV. Note that the lower two handaxes are relatively thinner, they have straighter edges, and are more symmetrical. Note that the lower pieces have been both invasively flaked to remove any cortex and were finished with small marginal trimming flakes
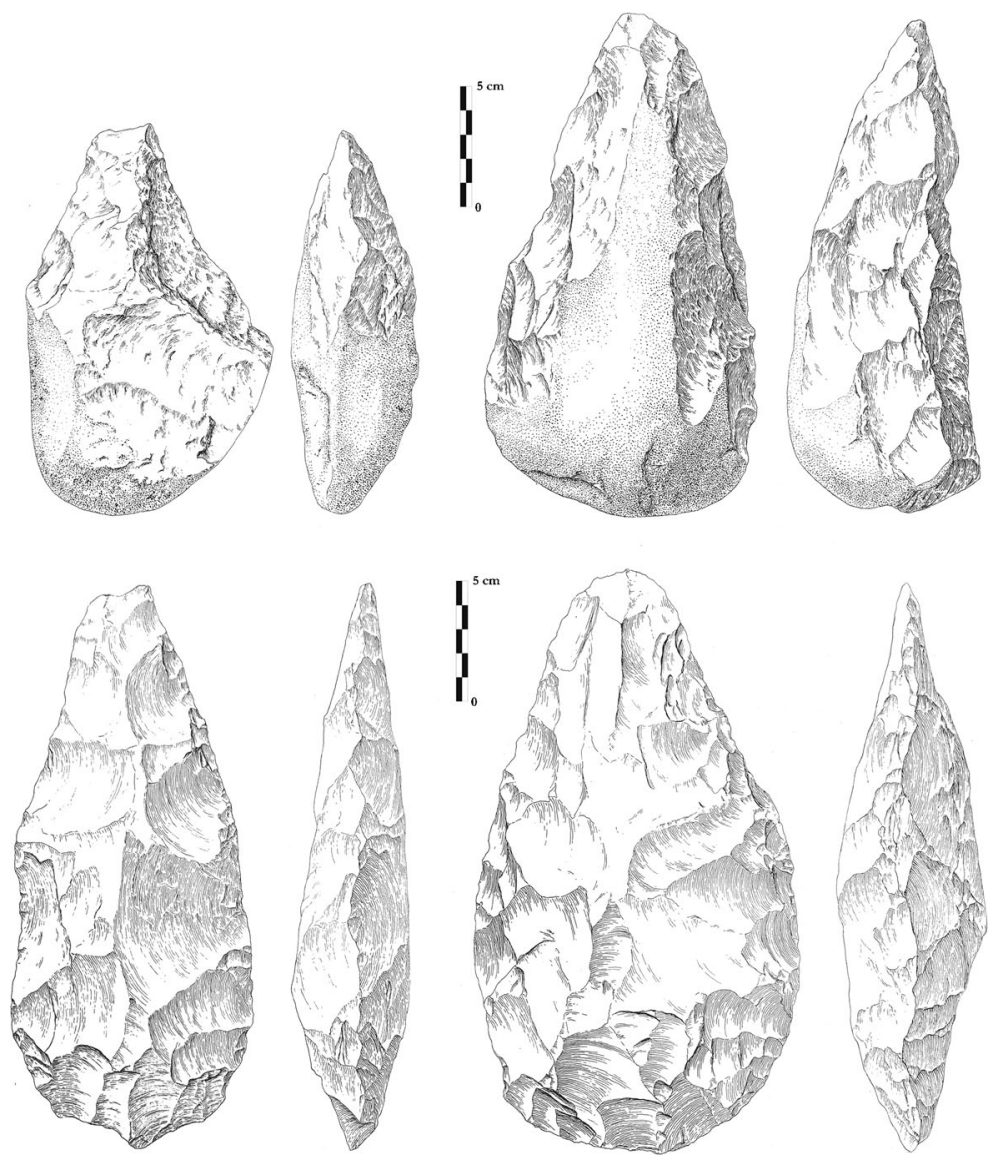

requiring different strategies; from roughing out a cobble or preparing a giant core, to thinning and shaping the blank (Newcomer 1971; Winton 2005).

Some studies have reported time trends in Acheulean bifaces, such as increasing mean thinness (Shipton 2013). In the Eastern Rift Valley, the early Acheulean bifaces from Peninj are relatively thicker and have fewer flake scars than those from younger assemblages at Olorgesailie (Isaac 1969). Melka Kunture, in the Upper Awash Valley of Ethiopia, sees the emergence of systematic methods for the production and shaping of large flake blanks into cleavers and handaxes over the period between 1.5 and 0.85 mya (Gallotti and Mussi 2017). In the Middle Awash Valley, bifaces have been shown to become smaller, more ovate, wider and thinner, more symmetrical, more intensively flaked, straighter edged, and to have a higher degree of standardisation from the Early to Middle Pleistocene (Schick and Toth 2017). In the Levant, where Acheulean sites span over a million years, it has been quantitatively demonstrated that bifaces become shorter, thinner, more regular in outline shape, and more symmetrical in plan form between 1.4 and 0.5 mya (Gilead 1970, 1977; Grosman et al. 2011a; Saragusti et al. 2005; Saragusti et al. 1998). At the late Acheulean site of Mieso 7 in Ethiopia, the final stage in cleaver production after the pieces had been thinned, was typically marginal trimming to regularise the planform shape (de la Torre et al. 2014). Similarly, at Wonderwerk Cave in South Africa, a sequence spanning hundreds of thousands of years has been documented in which the later handaxes are invasively flaked and then marginally trimmed to regularise the edge (Chazan 2015).

There are however, studies that have not found temporal trends in handaxe thinness or symmetry. Between the c. 1.5-million-year-old site of Rietputs 15 and the 0.5-million-year-old site of Cave of Hearths in southern Africa, no differences in handaxe thinness or plan and profile symmetry were observed ( $\mathrm{Li}$ et al. 2016). At sites in Britain and southern Africa, no increase in handaxe thinness or symmetry was found over time (McNabb 2013; McNabb and Cole 2015), though the symmetry 
measure used was subjective and not continuous (Underhill 2007). A study of European assemblages using a quantitative measure of symmetry and a greater age range of sites did find an increase over time (Iovita et al. 2017). The goal of this study is to quantitatively assess inter-site variation in Acheulean biface knapping outcomes in East Africa, using bifaces from the longue dureé site of Olduvai Gorge, the spatially variable site of Olorgesailie, and two other classic Acheulean sites nearby, Kariandusi and Isinya (previously Isenya) (Fig. 2).

\section{Biface Knapping Skill}

Knapping is a skill. It is not possible to simply pick up a couple of rocks and make a handaxe without prior practice (Geribàs et al. 2010). Assessing skill may be done in different ways. Technological studies of stone artefact reduction sequences have been able to identify the emergence of particular knapping techniques in the Acheulean such as platform preparation, marginal trimming, and the production of large elongate flake blanks (Chazan 2015; Shipton 2016; Stout et al. 2014). An alternative approach is to look at assemblage-level outcomes of reduction sequences, to directly compare between assemblages where different reduction strategies may have been used, and to determine what variables influence those outcomes. To do this requires identification of variables that are difficult to achieve so that they will differentiate skill levels, and to approximate the knapper's goals, in order to have a standard against which to judge success (Roux and David 2005; Stout 2002). Four variables were selected to represent biface knapping skill in this study: thinness, plan and profile symmetry, and edge straightness.

Creating thin, symmetrical bifaces with straight edges is difficult and, as anyone who has attempted to knap a biface knows, it will not happen by chance. In an experiment in which large flakes were removed from randomly determined platforms on a core, the nearest thing to a handaxe produced was a bifacial artefact lacking any imposed symmetry or thinning, and with an extremely crooked edge (see Fig. 16 in Moore and Perston 2016). Thus, it is not possible to recreate the shaping seen even in cruder Acheulean bifaces without the intention to do so.

There are several reasons to think that Acheulean hominins were trying to maximise biface thinness (commonly termed refinement [Roe 1994]). Experimental and archaeological evidence indicates that handaxes were cutting tools, used in both butchery and to a lesser extent, woodworking (e.g., Domínguez-Rodrigo et al. 2001; Galán and Domínguez-Rodrigo 2014; GorenInbar et al. 1994; Jones 1980; Key and Lycett 2017; Mitchell 1995; Piperno and Tagliacozzo 2001; Roberts and Parfitt 1999; Solodenko et al. 2015; Toth and Schick 2009). The function of cleavers is not well established as yet, but the morphology of their tips suggests they were chopping or slicing tools with experimental and archaeological wear supporting this (Claud et al. 2015; de la Torre et al. 2014; Shipton 2016). Biface sharpness is a function of edge angle, and because thinner bifaces have the potential for more acute edge angles, they have greater potential to be sharper. Bifaces were typically transported away from their sites of manufacture (e.g., Pope and Roberts 2005; Potts et al. 1999). The relatively
Fig. 2 The location of the sites in the Eastern Rift Valley. Map data from GeoMapApp (Ryan et al. 2009)

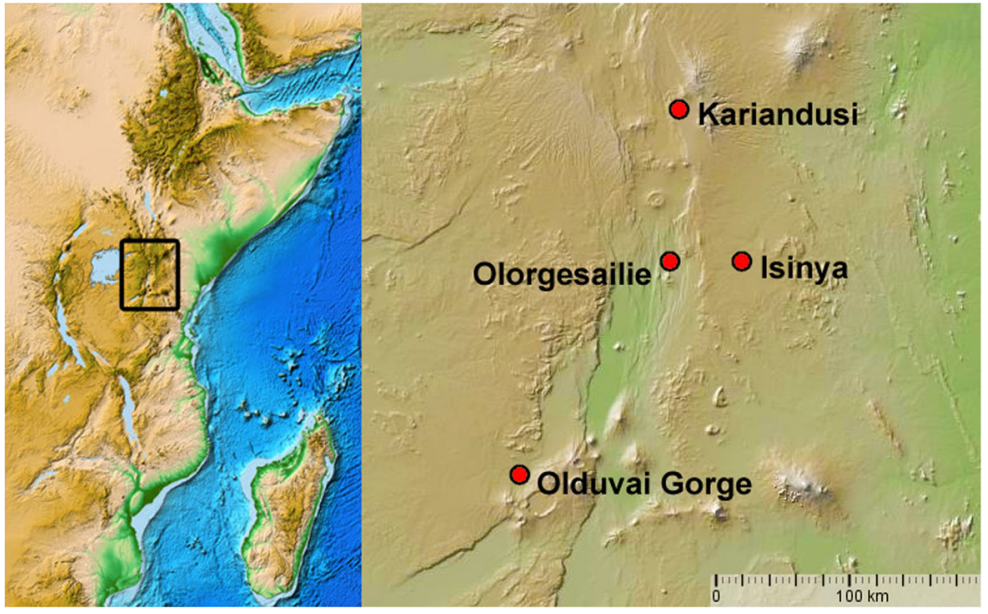


wider and thinner a biface is, the longer its cutting edge is relative to its weight, making it more efficient to transport. On a thinner biface, it is easier to maintain a secure opposing grip on each surface, a factor which is particularly relevant as a tool becomes covered in slippery blood and fat during butchery (McNabb 2005). A thinner tool will also be easier to manoeuvre in the narrow space between the skin and muscle. Other, perhaps secondary, functions of handaxes as cores (e.g., Roberts and Parfitt 1999) or as objects of display (e.g., Kohn and Mithen 1999) might also be enhanced by refinement. A thinner, wider biface may be reduced more extensively than a thicker narrower biface, as the flaking angle will become too great for further removals in the latter (McPherron 2000). Biface thinning flakes are also some of the largest produced in biface knapping, so thinner bifaces likely would have made better cores. Due to the difficulties in making a thin biface described above, thinness would be an effective way for a knapper to demonstrate their skill if these tools were objects of display.

Technological evidence corroborates the notion that Acheulean hominins were intending to make thin bifaces. In the late Acheulean, specific steps were taken to strike the highly invasive flakes required to thin bifaces, such as platform preparation and raising the plane of intersection (Stout et al. 2014). This was not simply a way of producing large flakes as there are far easier ways to achieve this. Earlier in the Acheulean, such techniques were not used, but there are cruder ways of attempting to thin a biface. Areas of high topography in the centre of bifaces were sometimes struck directly in attempts to remove them (Shipton 2013). High topography lumps can result from awkwardly shaped nodules or from repeated aberrant terminations, and they can be very difficult to remove once present. A tactic of last resort of Acheulean knappers was to flake the high topography lump directly, rather than approaching it from the edge and striking an invasive flake. Flaking a lump in the middle of a biface does not create a cutting edge, and there seems to be no good reason for doing this other than to thin the overall piece. Figure 3 shows an example of this phenomenon from Olorgesailie. Out of the sample of bifaces used in this study, every assemblage included examples of scars like those shown in Fig. 3, with intact initiations that were not on the edge of the biface.

Acheulean bifaces may be characterised as symmetrical objects. An experiment assessing the functional value of symmetry in handaxe butchery found "some support for the hypothesis that increasing frontal symmetry increases the effectiveness of handaxes as butchery tools" (Machin et al. 2007, p. 891) although the effect was weak. Others maintain that the primary purpose of handaxe symmetry is in its aesthetic value for display (Hodgson 2010; Kohn and Mithen 1999). There is a debate as to whether this symmetry was something deliberately imposed by hominins or was an unintentional by-product of creating and maintaining a bifacial edge (Hayden and Villeneuve 2009; Hodgson 2015; Li et al. 2016; Nowell 2002; Schoenemann 2002; Wynn $1995,2000,2002)$. Flake-made bifaces present the opportunity to test this issue as they have relatively few removals from the blank (Shipton and Clarkson 2015a), so the particular locations where hominins have chosen to remove mass are readily discernible. Cleavers in particular are informative, as their principal cutting edge, the straight tip, is invariably left unretouched, so removals are primarily to shape the overall tool rather than to create a cutting edge. Figure 4 shows an example
Fig. 3 A biface on a flake from Olorgesailie locality I3 (Upper Member 1) where the central ridge has been flaked. Note that the central ridge flakes were struck late in the reduction sequence as they truncate the large scar coming from the upper edge and the large scar coming from the butt. The series of scars struck from the butt do not alter the cutting edge and may also have been struck to thin the piece (photo: C. Shipton) (images in full colour online)

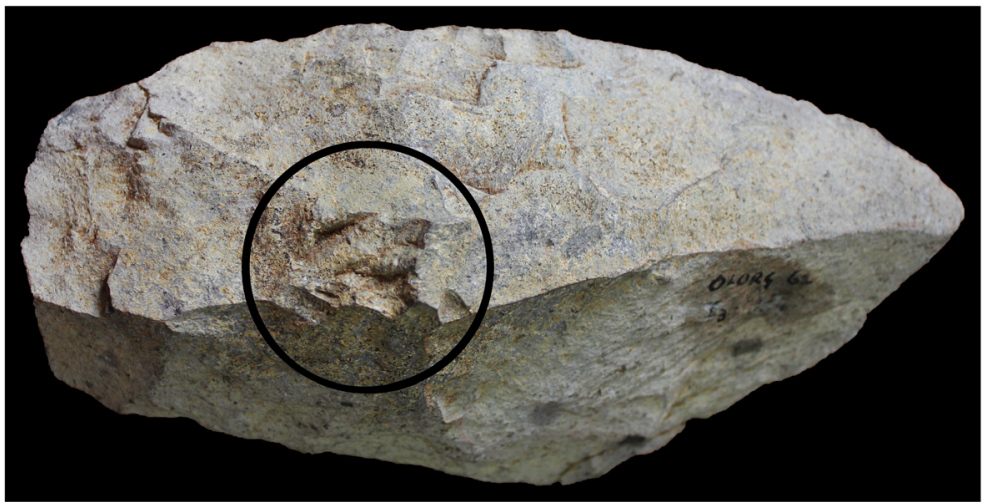




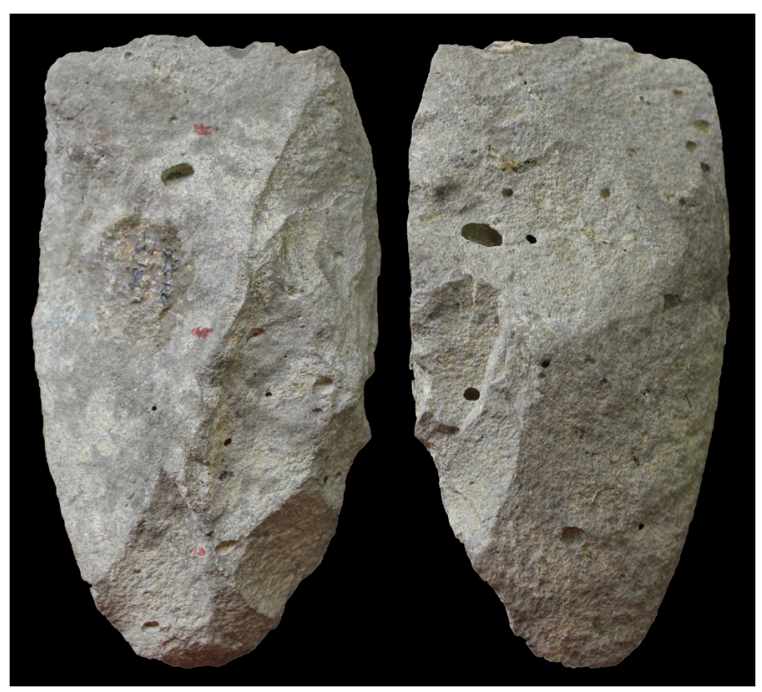

Fig. 4 A cleaver from Olorgesailie locality I3. Note how one edge has been retouched to mirror the form of the flake blank on the opposite edge. Note also that as this is a cleaver whose principal cutting edge is the distal bit; it is unlikely that this was done to create a cutting edge. The piece is $162 \mathrm{~mm}$ long (photo: C. Shipton)

of a cleaver from Olorgesailie where one edge has been left unretouched, while the opposite edge has been worked bifacially so that its shape mirrors that of the unretouched edge. Figure 5 shows more examples of cleavers from Isinya in which symmetry was imposed in a variety of different ways, including without bifacial flaking. Whichever purpose handaxe symmetry served, it seems it was achieved in a variety of ways and was something deliberately imposed by hominins.

Handaxe edge straightness has not yet received much attention as a variable influencing the utility of a cutting tool. However, cutting edges that dramatically changed direction along their length would probably be more difficult to use than straighter edges (Fig. 1). In the above-mentioned handaxe butchery experiment, one of the butchers complained of the handaxe edge: "the angle I'm finding really hard because it's kind of asymmetrical" (Machin et al. 2007). A key attribute of modern knives is a straight edge. Edge straightness, plan and profile symmetry, and refinement may all relate to the utility of a handaxe. As the cutting edge of cleavers is at their distal end, profile symmetry and edge straightness were probably less of a concern for these tools (Hodgson 2011).

Producing a thin biface usually requires either striking a large, thin flake blank or reducing an amorphous cobble into a lenticular shape. Thinning a biface blank involves raising the plane of intersection and creating strong platforms to strike invasive flakes nearly perpendicular to the surface being thinned (Callahan 1979). Stepped and hinged flake scars must be avoided or removed, to allow flakes to travel across the surface (Edwards 2001). The easiest flake removals must often be ignored in order to maintain adequate edge angles and control the overall form of the piece. Flakes struck must be invasive enough to travel at least to the midline of the biface to remove mass from the centre (Callahan 1979). The thinner a biface is, the more liable it is to break due to end-shock during manufacture. This may be avoided with delicate and precise flaking, as well as cushioning the blow and the detachment with the secondary hand holding the biface (Jones 1994). More skilled knappers should be able to straighten a bifacial edge more effectively, through a greater frequency of delicate removals, while fewer blows with a large heavy hammer will leave an uneven edge. To manage plan symmetry, the bifacial edge must be extended around much of the perimeter of the piece; while managing profile symmetry requires controlling the plane of

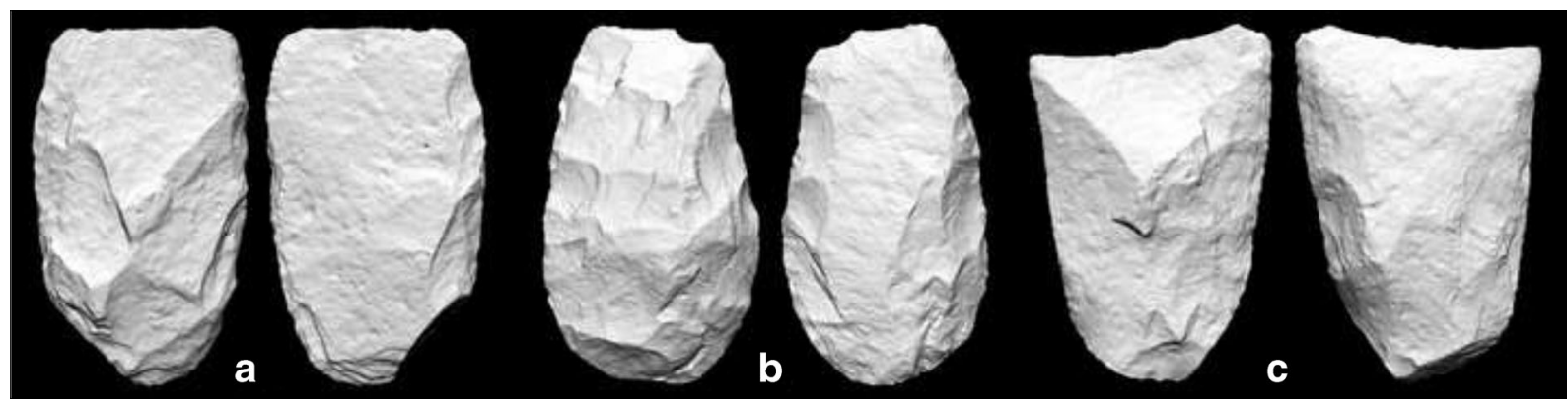

Fig. 5 Three flake cleavers from Isinya in which plan symmetry has been imposed in different ways. Cleaver A has been invasively bifacially flaked on one edge and marginally bifacially trimmed on the opposing edge. Cleaver B has been invasively bifacially flaked around the entire circumference except for the distal tip. Cleaver C is bifacially flaked on one edge and unifacially flaked on the opposite edge (photo: C. Shipton) 
intersection between the two hemispheres, and invasive flaking to remove mass from the points of high topography on either surface.

Knapping experiments confirm that more skilled knappers are better at maximising thinness, symmetry, and straight edges in practice. An experiment comparing 49 handaxes made by five knappers of different skill levels showed that more skilled knappers were able to produce thinner bifaces that were also qualitatively judged to be more symmetrical and with more regular profiles (Winton 2005). Another experiment comparing 52 handaxes, made by six knappers of varying skill levels, again found that the more skilled knappers produced thinner handaxes (Herzlinger et al. 2017), while qualitative adjudication of knapping in 134 bifaces also indicated that cross-section morphology and edge straightness are key differentiators of beginners and experts (Shelley 1990). Another experimental study with 24 bifaces (albeit not Acheulean-style ones) has shown that experts are distinguished from novices by their ability to impose symmetry in multiple planes (Darmark 2010). Variation in the symmetry of archaeological bifacial points has been shown to correlate with knapping errors, such that bifaces with fewer knapping errors are more symmetrical (Darmark 2010).

Archaeological evidence indicates that the refinement and symmetry of Acheulean bifaces were properties intentionally imposed by hominins (Figs. 3, 4, and 5 ). Given the cutting function of handaxes, it is likely that a straight edge was also a desirable feature for Acheulean knappers. If the goal in biface manufacture was to create thin, symmetrical, straight-edged pieces, then the lack of motivation amongst hominins to enhance such variables can be disregarded as a mitigating factor, as would be necessary with behavioural studies of living subjects (Jordan 2002). Making thin, symmetrical, straight-edged bifaces is difficult, and to become better at this requires enhanced knapping skill. These variables also reflect what Louis Leakey and Glynn Isaac were looking for in their assessments of Acheulean biface quality. Louis Leakey's (1951) subjective descriptions of biface quality were concerned with both plan and profile symmetry and the straightness of the edge, while Isaac (1972) favoured the objective metric of relative thinness. Subsequent researchers have also considered these variables when assessing how well Acheulean bifaces were made (e.g., Sahnouni et al. 2013; Schick and Clark 2003; Schick and Toth 2017; Wynn 2002). The approach taken in this paper is to measure these variables quantitatively, so that they may be compared statistically between assemblages, and that the correlation between variables can be tested.

\section{Samples}

Bifaces of ambiguous typology that might conceivably be classed as picks, discoids, or anything other than handaxes or cleavers were excluded from this study. As post-depositional processes have been shown to affect symmetry (Grosman et al. 2011b), bifaces that exhibited more than minor damage were excluded (damage was assessed on a 1-4 ordinal scale with 1 being undamaged, 2 minor damage, 3 moderate, and 4 extensive). Bifaces that were weathered, or rolled, to the extent that flake scar boundaries might be obscured, were also excluded (weathering/rolling were assessed on a 1-4 ordinal scale with 1 being fresh, 2 moderate, 3 weathered or rolled, and 4 heavily weathered or rolled). While these measures are subjective, all samples were assessed by the author only.

The Olduvai Gorge sample comprised those bifaces exported by Louis Leakey to the Institute of Archaeology, London, the Cambridge Museum of Archaeology and Anthropology, and the British Museum (see Appendix A1 for sample numbers). The bifaces are from the first excavations at Olduvai between 1931 and 1934, when the standard practice was to divide the collections and send representative samples to different museums. In his publication of these excavations, Leakey (1951) selected the most derived specimens from each of his successive stages for illustration, including some of the bifaces analysed here. Discounting the locality HK Bed IV where numerous bifaces were excavated, Leakey (1951) illustrated 76 bifaces in his book, $12 \%$ of the total in situ assemblage $(N=626)$. To test if there was a bias in the specimens Leakey selected for export to the UK, the proportion of bifaces illustrated in Leakey (1951) was compared between the sample of exported bifaces used here and the total in situ bifaces. Eighteen of 107 bifaces (17\%) in the exported sample were illustrated, which a chi-square test showed was not significantly different from the total $(P=0.21)$. The bifaces from the early excavation at Olduvai Gorge that were not exported are included in the online Acheulian Biface Database (Marshall et al. 2002). To further test if there was bias in Leakey's selection of samples for export, the levels of refinement were compared for 
Bed IV which has large samples of both exported and non-exported bifaces. An equal variances $t$ test showed no significant difference, indicating Leakey's export selection was not biased towards thinner bifaces (difference between the means $=0.00976$, standard error of difference $=0.0225, t=0.435, \mathrm{df}=85, P=0.665$ ).

When broken, rolled, and typologically ambiguous specimens were excluded from the Olduvai sample used in this study, it was reduced to 98. Minor stratigraphic revisions have been made to the Olduvai sequence after Louis Leakey worked there, mainly in relation to the boundary between Bed III and Bed IV at some localities (Hay 1971, 1976); therefore, only bifaces that could be assigned to both a locality and a bed were included in analyses involving stratigraphy. The Olduvai sequence is dated by palaeomagnetism, direct Argon-Argon dating of tephras, and geochemical fingerprinting of tephras to other eruptions of known age. The Olduvai specimens cover the temporal range from c. 1.7 to 0.6 mya (Hay 1976; McHenry et al. 2008; Tamrat et al. 1995), and were divided into two groups for the stratigraphic analyses: those from Bed II (1.781.19 mya) and those from Bed IV (0.83-0.6 mya). It should be noted that there is some uncertainty as to whether the reversal at the end of Bed IV represents the Jaramillo subchron or the Brunhes chron, so the end of Bed II and the period covered by Bed IV could both be somewhat earlier than the above ranges. Whichever interpretation of the Oludvai sequence is favoured, the Bed IV biface sample is several hundred thousand years younger than the sample from Bed II.

For Olorgesailie, Kariandusi, and Isinya, a random selection of bifaces was chosen, supplemented by all bifaces of exotic materials to increase the within-site diversity in this variable. The biface sample from Olorgesailie was excavated by Glynn Isaac and Rick Potts and is housed in the National Museums of Kenya (see Appendix A2 for specimen numbers). Bifaces were sampled from three horizons dated by tephrochronology and palaeomagnetism: CL1-1 dated to between 1.2 and 0.992 mya, Member 1 dated to 0.992 mya, and Member 6/7 dated to c. 0.939 mya (Durkee and Brown 2014; Isaac and Isaac 1977; Owen et al. 2008; Potts et al. 1999).

For Kariandusi, bifaces were selected from the National Museums of Kenya as well as a small sample from the Pitt Rivers Museum (see Appendix A3 for specimen numbers), and include artefacts from both Locus 1 and Locus 2, excavated by Louis Leakey in
1929 and 1931 (Shipton 2011). Kariandusi presents another opportunity to test if there was selection bias in what Leakey exported, by comparing the refinement of those selected from the Kenya National Museum with a sample of those exported to the Cambridge Museum of Archaeology and Anthropology that were measured for a previous study (Petraglia and Shipton 2008). An equal variances $t$ test showed no significant difference in refinement between the two samples (difference between the means $=0.009$, standard error of difference $=$ $0.021, t=0.444, \mathrm{df}=80, P=0.66$ ), suggesting there was no bias in Leakey's selection for export. The base of the Kariandusi sequence is the Gilgil trachyte which has been dated by Argon-Argon to 0.987 mya; on top of this is a thick diatomite deposit overlying a tephra dated to 0.977 mya (Trauth et al. 2005). The artefacts in turn occur above this diatomite deposit, and they are in fact mostly made on the Gilgil trachyte.

The Isinya bifaces were excavated by Hélène Roche and colleagues and are housed in the National Museums of Kenya (see Appendix A4 for specimen numbers), with the sample derived from across the $50-\mathrm{cm}$ thick sequence of artefact-bearing layers (V, VIa, VIb, and VIc) (Roche et al. 1988). The same tephra dated to 0.977 mya at Kariandusi overlies the artefacts at Isinya (Durkee and Brown 2014).

Table 1 shows the breakdown of bifaces by stratigraphy, type, and blank. Note that bifaces were only assigned to core or flake blanks where this was unambiguous (i.e., a clear ventral surface or some cortex on both surfaces), and otherwise, they were designated as unknown. The Olorgesailie, Kariandusi, and Isinya localities are all intermediate in age between Beds II and IV at Olduvai Gorge, falling in the time range of Bed III. This sample thus allows for a deep-time perspective on knapping skill at a single site with a relatively constant range of rock types available, and a horizontally variable perspective on a number of sites of intermediate age.

\section{Method}

Bifaces were scanned using a NextEngine 3D laser scanner. As described above, the four variables chosen to represent biface knapping skill were thinness, edge straightness, and plan and profile symmetry. The scans were firstly manually orientated to maximise their plan and profile symmetries using the CAD tools in the program ScanStudio. 
Table 1 Breakdown of assemblages by biface type and blank form

\begin{tabular}{|c|c|c|c|c|c|c|}
\hline Site & $\begin{array}{l}\text { Biface } \\
\text { Handaxe }\end{array}$ & $\begin{array}{l}\text { Type } \\
\text { Cleaver }\end{array}$ & Total & $\begin{array}{l}\text { Blank } \\
\text { Flake }\end{array}$ & $\begin{array}{l}\text { Form } \\
\text { Core }\end{array}$ & Unknown \\
\hline Olduvai Bed II & 24 & 3 & 27 & 4 & 5 & 18 \\
\hline Olduvai Bed III & 5 & 2 & 7 & 2 & 1 & 4 \\
\hline Olduvai Bed IV and Masek & 30 & 6 & 36 & 6 & 11 & 19 \\
\hline Olduvai uncertain provenance & 24 & 4 & 28 & 6 & 7 & 15 \\
\hline Olorgesailie CL1-1 & 4 & 26 & 30 & 27 & 0 & 3 \\
\hline Olorgesailie Upper Member 1 & 18 & 6 & 24 & 10 & 1 & 13 \\
\hline Olorgesailie Member 6/7 & 16 & 20 & 36 & 22 & 1 & 13 \\
\hline Kariandusi & 65 & 13 & 78 & 41 & 2 & 39 \\
\hline Isinya & 18 & 16 & 34 & 16 & 1 & 17 \\
\hline Total & 203 & 97 & 305 & 123 & 22 & 130 \\
\hline
\end{tabular}

Thinness was measured by the widely used refinement index of thickness to width ratio (Roe 1969). Axial width and thickness measurements were taken in the program Rapidworks as though a box were drawn around the biface, and only the sides of the box were being measured (as opposed to the absolute distance between the points of greatest width or thickness).

To measure edge straightness, handaxes were oriented in profile view in the program Rapidworks and then the distance between the maximum crest and trough of the bifacial edge was measured in the thickness (or profile) plane only (Fig. 6). Straighter edges will thus have a shorter distance between the maximum crests and troughs of the bifacial edge than wavier edges. This process was repeated for the left and right edges of the handaxe, and the mean was taken. The mean was then divided by the length of the handaxe to control for the overall size of the piece, as longer handaxes have more distance over which the crests and troughs can oscillate. Length was measured as though a box was drawn around the oriented handaxe and only the length axis of the box was being measured. Note that what is being measured with this edge straightness variable is not the fine serrations of every alternate flake scar that may provide important functional properties to the handaxe, but instead the maximum variation of the edge position in relation to the profile orientation of the handaxe.

Symmetry was assessed quantitatively using the Flip Test (Hardaker and Dunn 2005), from screen capture shots of the oriented scans of the bifaces in ScanStudio. The Flip Test mirrors a 2D image of an artefact and calculates the area of the image that does not fall within the mirror image of the other half of the artefact. Both plan and profile symmetries were measured in this way. Experimental evidence has shown that the Flip Test, when used for multiple symmetry planes on bifaces, is effective at discriminating knappers of different skill levels (Darmark 2010). Profile symmetry was measured on both the left and right profile views, and then the mean symmetry value was taken.

As invasiveness of flaking and the management of aberrant terminations are thought to be important components of biface knapping skill, these variables were also measured. Aberrant terminations were measured by counting the proportion of flake scars that ended in hinge or step terminations. Invasiveness of flaking was quantified by measuring the length along the flaking axis of the five largest flake scars on each surface of the biface (using the edge of the biface as the minimum initiation point), averaging these ten measurements, and then dividing by biface length to control for the size of the piece. As knapped stone is a reductive technology, reduction intensity is critical for assessing variation (McPherron 2006; Shipton and Clarkson 2015b). Flake scar density has been experimentally demonstrated to predict reduction intensity in handaxes and was calculated here from biface scans according to the protocols outlined in (Shipton and Clarkson 2015a).

\section{Analysis}

Handaxes and cleavers were analysed together for refinement and plan symmetry, while handaxes were analysed on their own for edge straightness and profile 
Fig. 6 The edge straightness measure on three handaxe profiles from Olduvai Gorge. The arrows indicate the deepest peak and highest trough on each edge. The handaxe on the left is from Bed II, and the two on the right are from Bed IV (photos: C. Shipton)

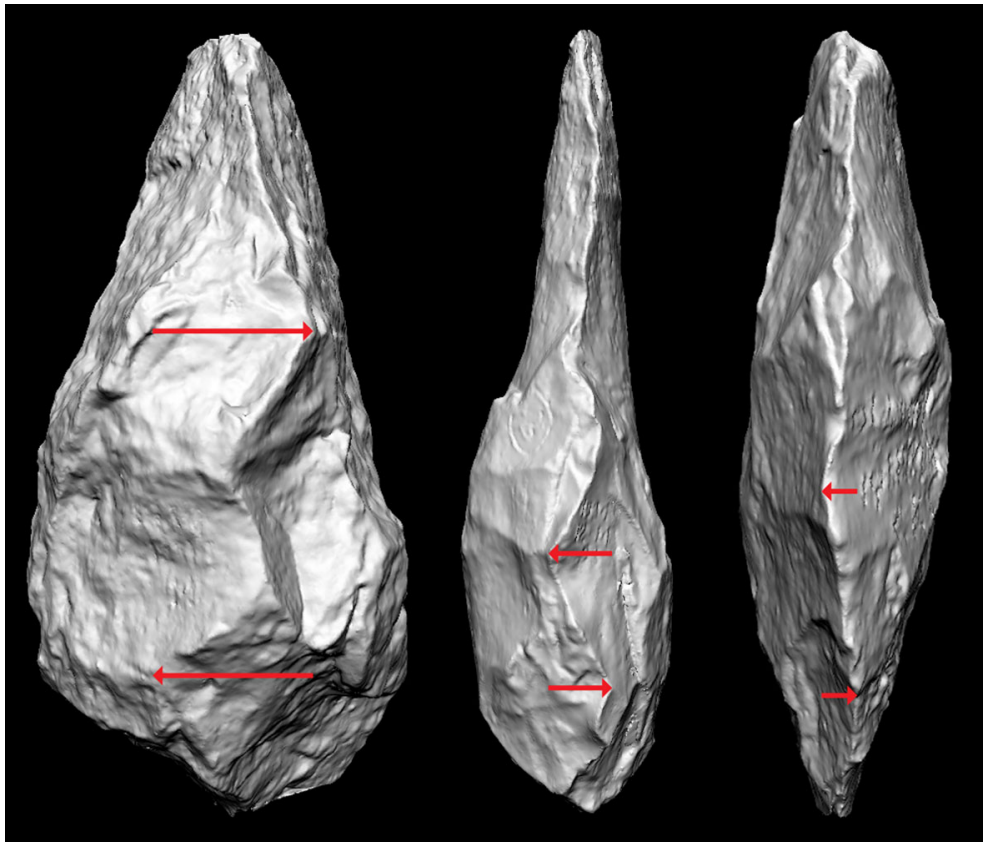

symmetry. The first round of analysis looked only at bifaces from Olduvai Gorge to examine long-term progression in the test variables while minimising confounding factors that may vary between sites. To test for chronological trends, bifaces were compared between Beds II and IV (sample size for Bed III was too low). Mann-Whitney $U$ tests were used to compare refinement and plan symmetry, as well as edge straightness and profile symmetry for handaxes (Table 2, Fig. 7). There is indeed a significant improvement in all four test variables across the Olduvai Acheulean sequence.

To determine if there were corresponding chronological patterns in invasiveness of flaking, the proportion of aberrant terminations, and scar density, these variables were also compared between Beds II and IV (Table 3, Fig. 8). The results show no difference in the percent of aberrant terminations, but an increase in the invasiveness of flaking and scar density, suggesting the latter two may in part underpin the increases in refinement, edge straightness, and symmetry between the beds.

Rock type is thought to be an important influence on biface knapping in general (Lycett and von CramonTaubadel 2014; Noll 2000; Nowell 2002) and at Olduvai Gorge in particular (Jones 1979). Experimental knapping using materials from Olduvai indicates that the quartzite (which is nearly pure quartz at Olduvai [Hay 1971]), phonolite, and the coarser-grained lavas (basalt and trachyandesite) have different flaking qualities and require different approaches (Jones 1994). To test how these flaking properties influenced the test variables, Kruskall-Wallis tests were conducted with the three material types as the independent variable (Table 4). Rock type was a significant influence, with phonolite bifaces being the most refined, with the straightest edges, and most symmetrical in profile. This accords with the experimental observations on the knapping qualities of phonolite (Jones 1994). Phonolite blanks

Table 2 Mann-Whitney $U$ tests comparing biface refinement, symmetry, and edge straightness between Beds II and IV at Olduvai Gorge

\begin{tabular}{llllr}
\hline Variable & $N$ & Mean rank difference & $U$ & Significance \\
\hline Refinement & 60 & 17.38 & 184 & $<0.001$ \\
Plan symmetry & 56 & 15.8 & 163 & $<0.001$ \\
Profile symmetry & 46 & 9.95 & 143 & 0.014 \\
Edge straightness & 49 & 9.21 & 181 & 0.027 \\
\hline
\end{tabular}



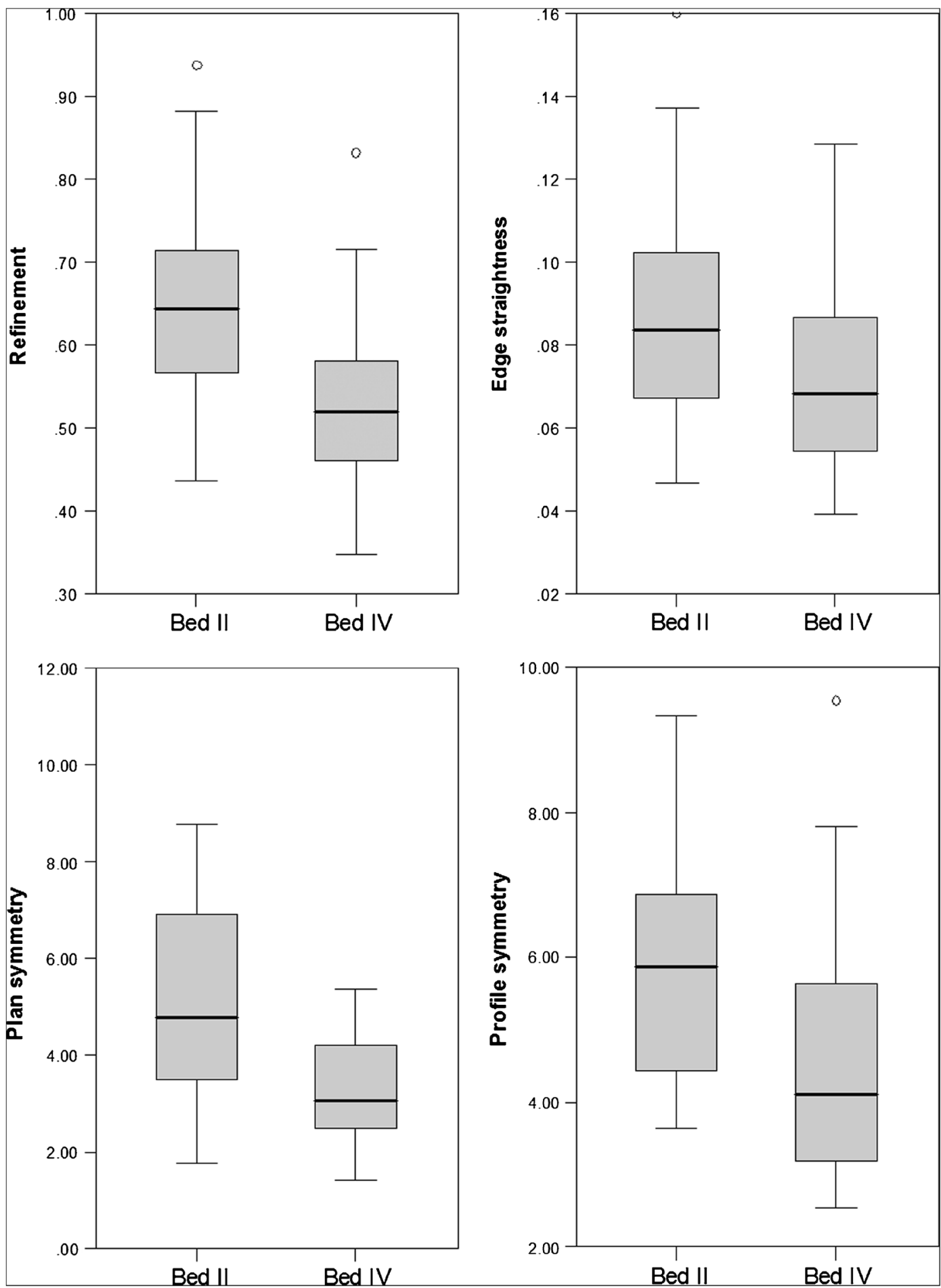

Fig. 7 Boxplots of biface refinement, edge straightness, and symmetry in Beds II and IV at Olduvai Gorge

are either thin slabs or large flakes so that refinement can be achieved even without invasive flaking. It is also very brittle, so it fractures easily and can be subjected to the fine retouch required to control profile symmetry and straighten the edge. The influence of rock type may in part be responsible for the differences in the test 
Table 3 Mann-Whitney $U$ tests comparing the proportion of aberrant terminations and the invasiveness of flaking between Beds II and IV at Olduvai Gorge

\begin{tabular}{llllr}
\hline Variable & $N$ & Mean rank difference & $U$ & Significance \\
\hline Percent aberrant & 63 & 2.3 & 450.5 & 0.622 \\
Invasiveness & 62 & 10 & 317 & 0.031 \\
Scar density & 62 & 19.15 & 179 & $<0.001$ \\
\hline
\end{tabular}

variables observed between Beds II and IV, as there were more phonolite bifaces in the Bed IV sample. As quartzite and lava bifaces had very similar overall tendencies for refinement and edge straightness, it was possible to compare these two variables for quartz and lava bifaces between Beds II and IV. The results of the Mann-Whitney $U$ test indicate that even within these coarser-grained materials, there is still a significant difference between refinement and edge straightness between the beds (Table 5).

Initial blank form is thought to be another important influence on biface knapping (White 1998). To test for the influences of blank type on the test variables, MannWhitney $U$ tests were conducted between flake and core bifaces at Olduvai Gorge (Table 6). The results show blank type was not a significant influence on any of the test variables. This may be because the core blanks at Olduvai, where identifiable, were mostly slabs, which have a similar thin tabular morphology to flake blanks.

The next stage of analysis introduced bifaces from three other sites in East Africa: Olorgesailie, Kariandusi, and Isinya. All three sites thus fall in the time range of
Bed III at Olduvai Gorge, allowing an assessment of whether they are intermediate in the schema of progressive improvement at Olduvai Gorge, and whether changes can be detected on a finer timescale than between Olduvai Beds II and IV. Kruskal-Wallis tests showed significant differences across the assemblages in all four test variables (Table 7). When the variables were plotted, however, the assemblages did not fall into chronological order, with some having values higher than those of Olduvai Bed II or lower than those of Olduvai Bed IV (Figs. 9 and 10). Some patterns occurred consistently, such as the older Olorgesailie Member $6 / 7$ bifaces (Fig. 11) always having lower values than the younger Olorgesailie Upper Member 1 (Table 8 , but note that they were not distinguishable for profile symmetry). Isinya usually had the lowest values of any of the assemblages (Fig. 12), even though the assemblage is older than Olduvai Bed IV (Table 9, but note that they were not distinguishable for profile symmetry).

At Olorgesailie, it has been suggested that rock type is the pre-eminent cause of variation in biface
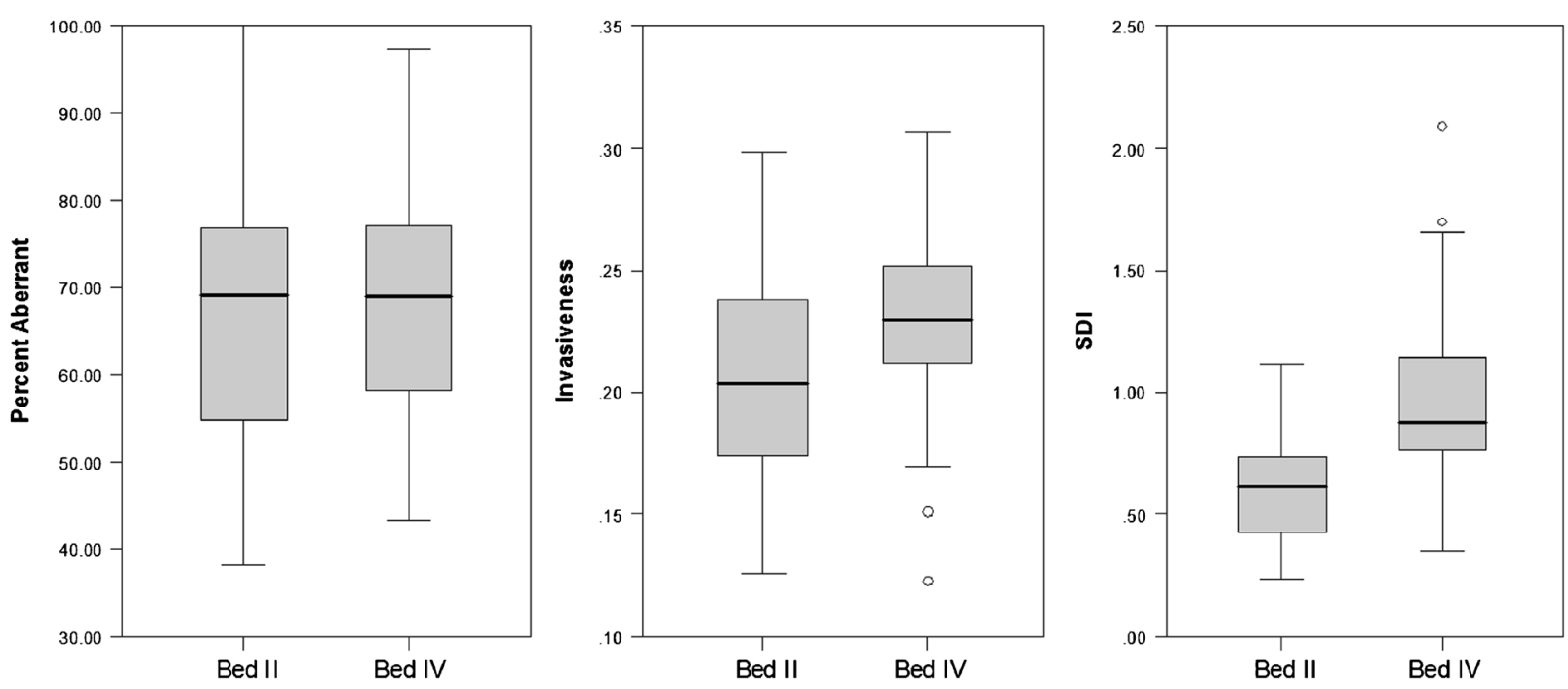

Fig. 8 Boxplot of aberrant terminations, invasiveness of flaking, and flake scar density (SDI) on bifaces from Beds II and IV at Olduvai Gorge 
Table 4 Results of Kruskal-Wallis tests comparing refinement, symmetry, and edge straightness between quartzite, phonolite, and coarsergrained lava bifaces from Olduvai Gorge

\begin{tabular}{lllllll}
\hline Variable & $N$ & Chi-Square & Significance & Phonolite median & Lava median & Quartz median \\
\hline Refinement & 96 & 8.44 & 0.015 & 0.475 & 0.567 & 0.565 \\
Edge straightness & 76 & 7.27 & 0.26 & 0.06 & 0.075 & 0.076 \\
Plan symmetry & 93 & 5.88 & 0.053 & 4.29 & 4.23 & 2.98 \\
Profile symmetry & 77 & 9.31 & 0.01 & 3.92 & 5.33 & 4.11 \\
\hline
\end{tabular}

morphology (Noll 2000). To test this, Mann-Whitney $U$ tests were used to compare the difference in refinement and plan symmetry (sample size was not large enough for edge straightness and profile symmetry), between the softer basalt and phenocryst rich trachyte (including trachyandesite) bifaces from Olorgesailie (Table 10). The lack of significant differences indicates that rock type was not a strong influence on the test variables at Olorgesailie. At Kariandusi and, to a lesser extent, Isinya, a minority of bifaces were made on cryptocrystalline obsidian and chert amongst assemblages dominated by microcrystalline trachyte and phonolite lavas. To test the influence of material at these sites, a MannWhitney $U$ test between microcrystalline and cryptocrystalline materials was run with the four test variables as the dependents (Table 11). The results indicate a significant influence of rock type on refinement and edge straightness but not symmetry, with cryptocrystalline materials being less refined and with fewer straight edges than microcrystalline. This may be because more brittle materials such as obsidian fracture more easily, resulting in larger bulbs of percussion. Without controlling the plane of intersection, a knock-on effect of this might be steeper flaking angles and thus less invasive flakes.

To assess the influence of blank type, Mann-Whitney $U$ tests compared core and flake blanks for the test variables across all the bifaces in the study (Table 12). The results showed that only for profile symmetry was there a significant difference, with flakes being less

Table 5 Mann-Whitney $U$ tests comparing refinement and edge straightness on quartzite and non-phonolite lava bifaces between Beds II and IV at Olduvai Gorge

\begin{tabular}{lcccl}
\hline Variable & $N$ & $\begin{array}{c}\text { Mean rank } \\
\text { difference }\end{array}$ & $U$ & Significance \\
\hline Refinement & 53 & 14.06 & 161 & 0.001 \\
Edge straightness & 40 & 7.62 & 121 & 0.042 \\
\hline
\end{tabular}

symmetrical. This is probably because the cross-section shape of flake-made bifaces is strongly determined by the curved cross-section of the initial flake blanks, as they do not tend to be heavily modified by retouch.

To determine the effects of reduction intensity, aberrant terminations, and scar density, four regression analyses were run on all bifaces with these variables as the independents and each of the test variables as the dependents (Table 13). All the models had extremely low $R$-squared values, and only refinement and edge straightness had significance levels less than 0.05 . The only significant individual independent variable was invasiveness, suggesting this has a weak effect on refinement and edge straightness, while aberrant terminations and reduction intensity do not appear to influence the test variables.

The final analysis used univariate general linear models (GLMs) to determine the relative influence of rock type, blank type, flake scar density, aberrant terminations, invasiveness, and assemblage (independent variables), on each of the test variables (dependent variables) (Table 14). For refinement, edge straightness, and plan symmetry, the most influential variable was the assemblage the bifaces belonged to. For profile symmetry, the most influential variable was blank type followed by the assemblage-blank interaction and assemblage-material interaction. As suggested above, this is likely due to the strong influence of flake blanks in cases where the ventral surface is still visible on the profile shape of a biface.

Scar density had a significant influence on refinement, possibly due to the longer reduction sequences required to thin some biface blanks. Both material and blank influenced refinement, as did the interaction between the two, probably because in some materials, it is possible to strike thin flake blanks while in others, only thicker cobbles were available. The model for edge straightness was the strongest overall, with an $R$-squared of 0.8. Assemblage had a strong effect on the edge straightness model, and the interaction between material 
Table 6 Mann-Whitney $U$ tests comparing refinement, symmetry, and edge straightness between flake and core bifaces from Olduvai Gorge

\begin{tabular}{lllrc}
\hline Variable & $N$ & Mean rank difference & $U$ & Significance \\
\hline Refinement & 38 & 3.52 & 147 & 0.328 \\
Plan symmetry & 35 & 2.54 & 130 & 0.466 \\
Profile symmetry & 22 & 5.19 & 19 & 0.148 \\
Edge straightness & 22 & 2.44 & 28 & 0.496 \\
\hline
\end{tabular}

and assemblage, and material and blank, also had strong effects. As stated above, materials that fracture more easily are likely to leave more wavy edges without specific techniques, such as marginal trimming and platform preparation, to counter this effect. The influence of scar density on edge straightness may reflect the use of marginal trimming to control this variable. Edge straightness was the only variable significantly influenced by invasiveness, perhaps because striking invasive flakes requires fine control of the edge. The relatively strong influence of the assemblage on all the test variables, (either on its own or as part of an interaction), indicates that there are underlying variables which vary by assemblage, other than rock type, blank type, reduction intensity, and invasiveness, that have a significant influence on the test variables.

\section{Discussion}

Biface morphology is subject to many different influences including the material on which it is made, the type of blank, and the degree to which it is reduced (Lycett and von Cramon-Taubadel 2014; McPherron 2006; Noll 2000; Nowell 2002; White 1998). However, these variables are not the be-all and end-all of biface variation, as skilled knappers can overcome such influences to produce similar forms (Eren et al. 2014).

Analysis of the test variables on the Olduvai Gorge bifaces showed that blank type had no discernible effect.

Table 7 Results of Kruskal-Wallis tests comparing refinement, symmetry, and edge straightness on bifaces between Olduvai Gorge Beds II and IV, Olorgesailie, Kariandusi, and Isinya

\begin{tabular}{lllr}
\hline Variable & $N$ & Chi-square & Significance \\
\hline Refinement & 229 & 56.921 & $<0.001$ \\
Edge straightness & 152 & 19.482 & 0.003 \\
Plan symmetry & 221 & 32.142 & $<0.001$ \\
Profile symmetry & 145 & 13.237 & 0.039 \\
\hline
\end{tabular}

When looking at all the bifaces in the sample, blank type had a significant influence on profile symmetry, probably because the curved profile of the flake blank largely determined the final profile. The GLM confirmed blank type accounted for around $17 \%$ of the variation in profile symmetry.

At Olduvai Gorge, rock type was a significant influence, with phonolite bifaces more refined and with more symmetrical profiles than coarser-grained lava and quartzite bifaces, probably due to the ease of flaking phonolite as compared to the other materials at Olduvai (Jones 1994). At Olorgesailie, rock type was not found to be a significant influence on any of the test variables. For Kariandusi and Isinya, rock type was found to have a significant effect on refinement and edge straightness, probably due to the ease with which different rocks fracture. The GLM confirmed that when interacting with assemblage and blank, rock type accounted for 22 and $12 \%$ of the variation in edge straightness respectively.

Although there was an increase in reduction intensity between Olduvai Gorge Beds II and IV, the regression analyses did not indicate a significant influence of reduction intensity on the test variables. The GLM did, however, find that scar density was a significant influence on refinement and edge straightness. In the case of refinement, this may be due to longer reduction sequences needed to thin bifaces; while in the case of edge straightness, this may be due to the use of marginal trimming to control the edge.

The proportion of aberrant terminations did not appear to have any significant influence on the test variables. The regression analyses indicated invasiveness of flaking was a significant influence on refinement and edge straightness, while the GLMs only found that it was a significant influence on edge straightness. An influence on refinement is easy to explain as thinning a biface often requires invasive flakes to be struck. The relationship to edge straightness is more obscure, but it may be that both require control of the bifacial edge. 
Fig. 9 Boxplots of biface refinement and edge straightness for some East African Acheulean assemblages. Note that Olorgesailie CL1-1 is not shown for edge straightness due to the low number of handaxes

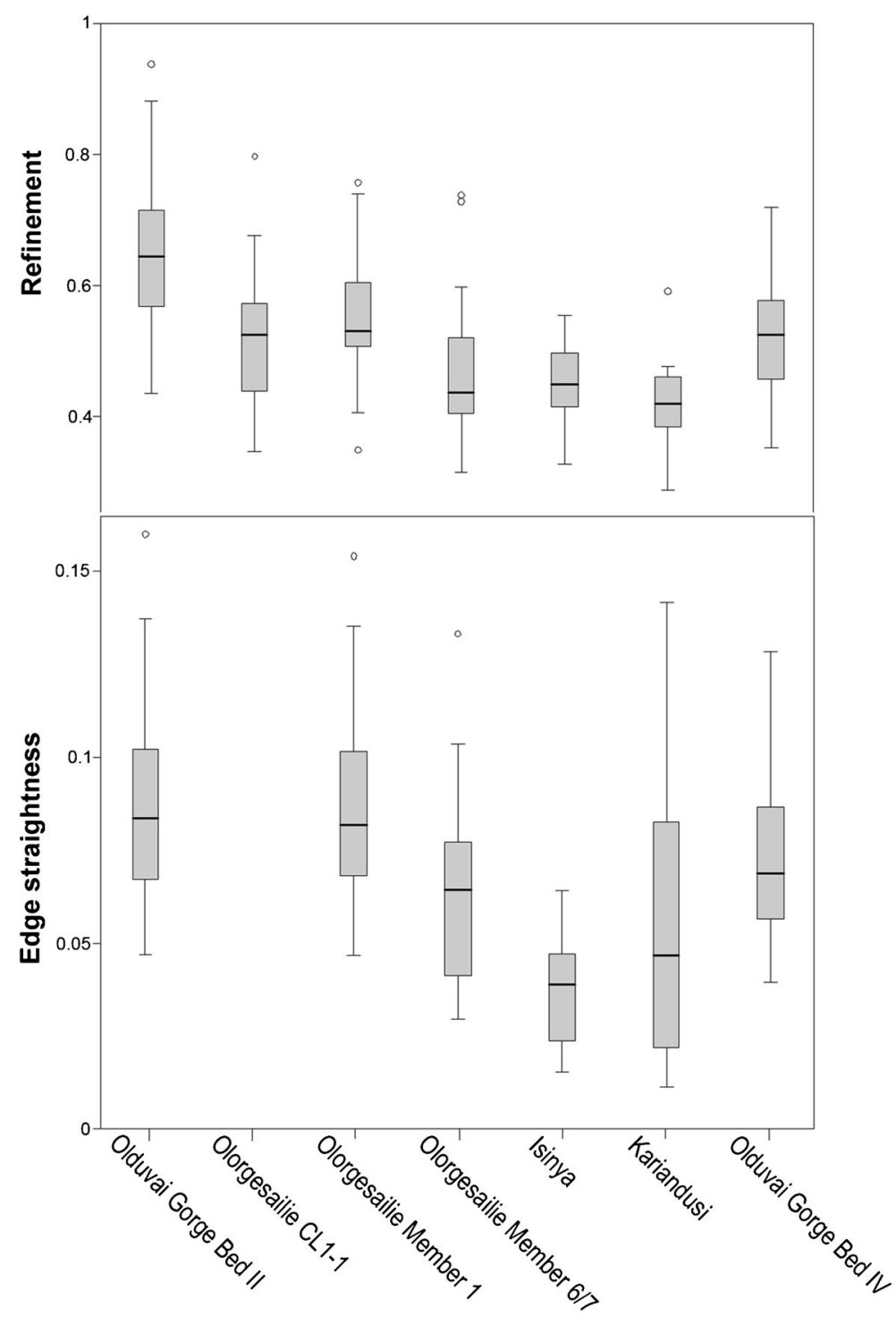

The GLMs indicated that the strongest influence on the test variables was the assemblage to which the samples belonged, suggesting variation between the knappers of the different assemblages beyond what can be accounted for by rock type, blank type, reduction intensity, and invasiveness of flaking. Other factors thought to influence biface shape which vary by assemblage include the physiology of the knappers as well as the cultural traditions of particular social groups (Isaac 1971; Machin 2009). There is significant morphological diversity within East African Homo erectus (sensu lato) around 1 mya (Potts et al. 2004) which may account for some variation in their bifaces. And, the Isinya bifaces, even though they are approximately contemporary to Kariandusi and Olorgesailie, appear to belong to a different knapping tradition in which great care was taken to shape elongate bifaces (Fig. 12).

The presumed functional value of the test variables should ensure that hominins were attempting to maximise these variables regardless of what other constraints were in play. Biface knapping requires significant cognitive resources and manipulative capability (Faisal et al. 2010; Hecht et al. 2015; Muller et al. 2017), with bifaces representing a minimum necessary level of competence on the part of their makers. However, due to 
Fig. 10 Boxplots of biface plan and profile symmetry for some East African Acheulean assemblages. Note that Olorgesailie CL1-1 is not shown for profile symmetry due to the low number of handaxes

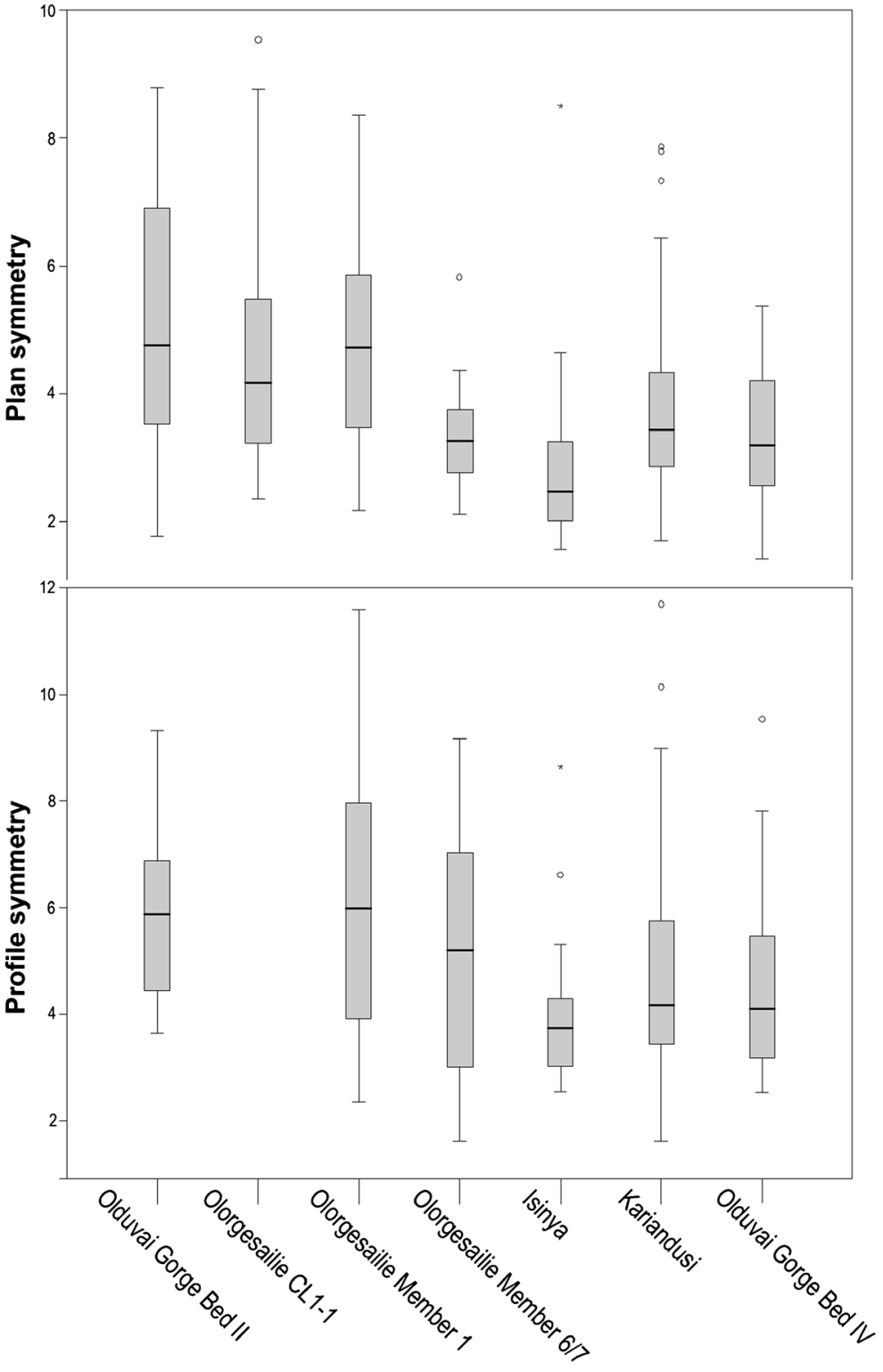

expediency, it is likely that knappers frequently did not produce the best bifaces they were actually capable of making.

In comparisons of multiple penecontemporaneous Acheulean sites, the combination and interaction of the many variables which have subtle influences on handaxe morphology obscure any short-term temporal signature in knapping skill, giving rise to the random walk pattern. However, when we look at the coarse resolution level of the different beds at Olduvai Gorge, there seems to be a marked increase in skill over the hundreds of thousands of years of Acheulean occupation there. As the Olduvai samples come from multiple different localities, the potential for only extremes of the random walk to be captured at particular localities is avoided. The temporal trend at Olduvai even occurs within the coarser-grained materials, so it is unlikely to be explained by rock type selection. Notably, the same pattern of increasing biface symmetry, refinement, and edge straightness has also been documented in the Acheulean of Ethiopia (Schick and Toth 2017). Four non-mutually exclusive explanations are considered to try to explain these long-term temporal trends in knapping skill. 


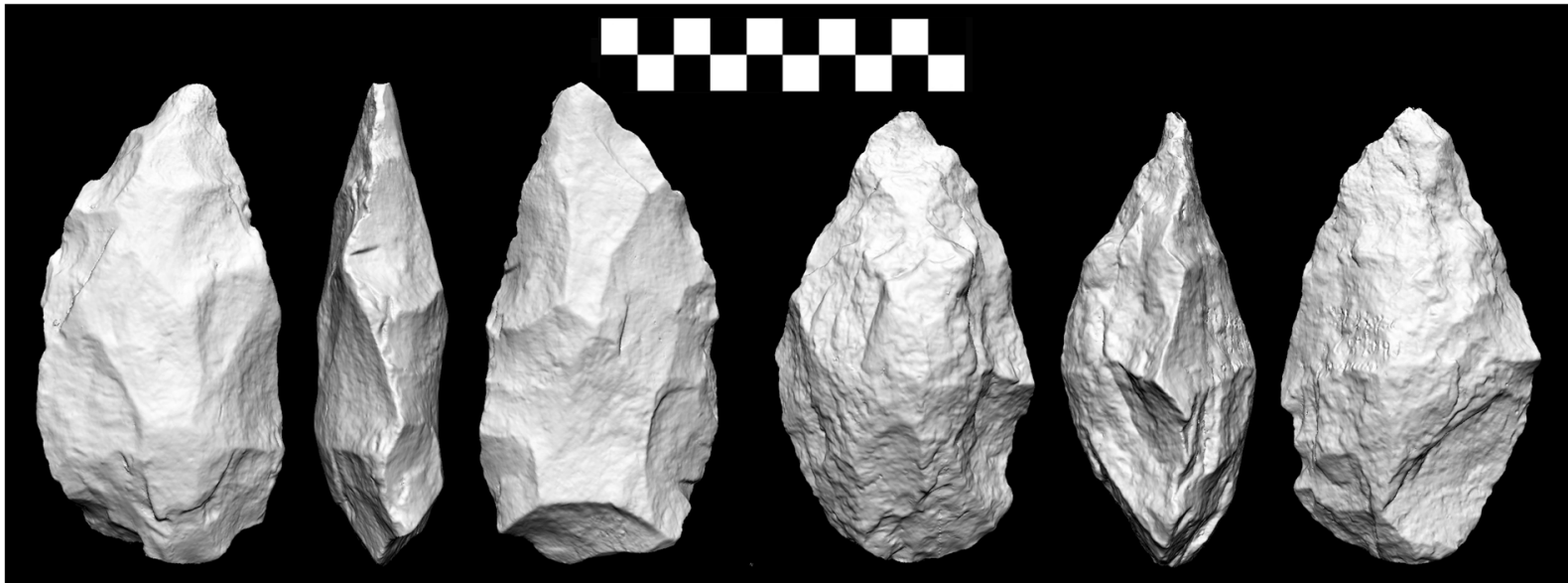

Fig. 11 Two handaxes from Olorgesailie Upper Member 1. Note the thickness and wavy edges (photos: C. Shipton)

Table 8 Results of Mann-Whitney $U$ tests comparing refinement, symmetry, and edge straightness between bifaces from Olorgesailie Upper Member 1 and Member 6/7

\begin{tabular}{lccrc}
\hline Variable & $N$ & $\begin{array}{l}\text { Mean rank } \\
\text { difference }\end{array}$ & $U$ & Significance \\
\hline Refinement & 56 & 15.68 & 169 & $<0.001$ \\
Edge & 30 & 6.99 & 59 & 0.031 \\
$\quad$ straightness & & & 148.5 & $<0.001$ \\
Plan symmetry & 54 & 15.86 & 71 & 0.482 \\
Profile & 27 & 2.22 & & \\
$\quad$ symmetry & & & & \\
\hline
\end{tabular}

One possibility is that derived features of the human hand evolved during the last 1.5 million years, allowing later Acheulean hominins greater manipulative abilities (Tocheri et al. 2008). However, recent evidence from fossils from East Africa and Iberia suggests a modern hand morphology was present by the time of the early Acheulean (Lorenzo et al. 2015; Ward et al. 2014), and it is possible that this, in conjunction with the large body size of Homo erectus, allowed for the strength and dexterity necessary to create the Acheulean. To produce the large flakes that occur in the East African Acheulean in some of the earliest assemblages, including Olduvai Gorge Bed II, requires a modern-like unrestrained wrist and the strength to exert high levels of manual pressure (Key et al. 2017; Williams et al. 2014).

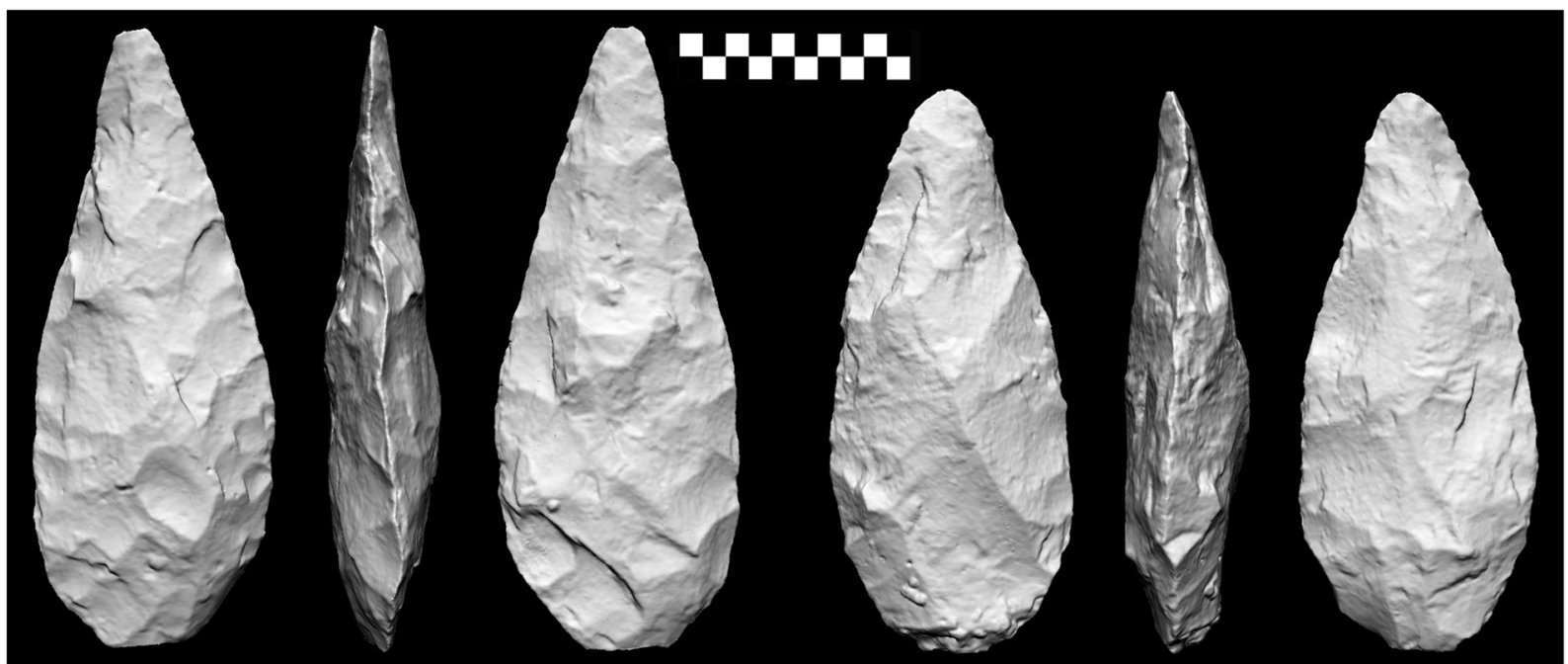

Fig. 12 Two handaxes from Isinya. Note the thinness, straight edges, and the high degree of symmetry (photos: C. Shipton) 
Table 9 Results of Mann-Whitney $U$ tests comparing refinement, symmetry, and edge straightness between bifaces from Olduvai Bed IV and Isinya

\begin{tabular}{lllrr}
\hline Variable & $N$ & $\begin{array}{l}\text { Mean rank } \\
\text { difference }\end{array}$ & $U$ & Significance \\
\hline Refinement & 66 & 16.18 & 316 & 0.001 \\
Edge straightness & 52 & 21.65 & 64 & $<0.001$ \\
Plan symmetry & 65 & 10.48 & 400 & 0.029 \\
Profile symmetry & 45 & 4.01 & 208 & 0.322 \\
\hline
\end{tabular}

The hominin brain saw significant changes during the course of the Acheulean. Overall brain size underwent its most rapid increase in hominin evolution, with body size remaining largely the same (Rightmire 2004; Ruff et al. 1997). Morphometric studies of fossil crania show that it is the frontal and parietal regions in particular which increased in size relative to the rest of the brain (Bruner 2010; Bruner and Holloway 2010). Neural imaging of modern subjects while they were knapping has shown that frontal and parietal regions of the brain are implicated in this task, with significantly more bilateral activity in the two hemispheres when replicating refined late Acheulean handaxes as opposed to Oldowan technology (Hecht et al. 2015; Stout et al. 2011; Stout et al. 2008). Comparable manipulative complexity in these tasks suggests the differences in brain activation are due to supra-ordinate organisation of knapping in a hierarchically structured sequence, as opposed to the differentiation of grips in the non-dominant and dominant hand (Faisal et al. 2010). Increased action planning may have allowed later hominins to anticipate knapping obstacles and structure their knapping sequences, as experimental evidence indicates is essential for advanced handaxe knapping (Muller et al. 2017; Newcomer 1971; Winton 2005). The addition of new stages to handaxe knapping sequences is witnessed in the marginal trimming documented at

Table 10 Results of Mann-Whitney $U$ tests comparing refinement and plan symmetry between trachyte (including trachyandesite) and basalt bifaces from Olorgesailie

\begin{tabular}{lllll}
\hline Variable & $N$ & $\begin{array}{l}\text { Mean rank } \\
\text { difference }\end{array}$ & $U$ & Significance \\
\hline Refinement & 83 & 3.18 & 794 & 0.548 \\
Plan symmetry & 82 & 4.93 & 739 & 0.349 \\
\hline
\end{tabular}

Table 11 Results of Mann-Whitney $U$ tests comparing refinement, symmetry, and edge straightness between microcrystalline and cryptocrystalline bifaces from Kariandusi and Isinya

\begin{tabular}{lrlll}
\hline Variable & $N$ & $\begin{array}{l}\text { Mean rank } \\
\text { difference }\end{array}$ & $U$ & Significance \\
\hline Refinement & 105 & 23.61 & 431 & 0.003 \\
Edge straightness & 84 & 18.3 & 292 & 0.008 \\
Plan symmetry & 103 & 6.62 & 606.5 & 0.415 \\
Profile symmetry & 76 & 8.98 & 273 & 0.212 \\
\hline
\end{tabular}

sites like Wonderwerk Cave and Miseo (Chazan 2015; de la Torre et al. 2014). Increased action planning may also be partly reflected in the subtle influence of scar density on refinement and edge straightness and the increased scar density between Beds II and IV at Olduvai Gorge.

Particular knapping techniques, including the use of soft hammers, raising the plane of intersection, and platform faceting, were likely invented during the Acheulean, and the addition of these may have allowed for improvements in knapping. One of the earliest uses of soft-hammer flaking has been suggested for the c. 0.7-0.8-mya Acheulean site of Gesher Benot Ya'aqov (Sharon and Goren-Inbar 1999), while both soft hammer and platform preparation have been unequivocally demonstrated at the 0.5-mya Acheulean site of Boxgrove (Pitts and Roberts 1997; Stout et al. 2014). Given the neurological evidence for hierarchical organisation in late Acheulean knapping, the incorporation of additional knapping phases involving soft hammers, platform preparation, and raising the plane of intersection into Acheulean reduction sequences, may have been facilitated by cognitive changes. The increased invasiveness of flaking between Beds II and IV at Olduvai

Table 12 Results of Mann-Whitney $U$ tests comparing refinement, symmetry, and edge straightness between flake and core blank bifaces from Olduvai Gorge, Olorgesailie, Kariandusi, and Isinya

\begin{tabular}{lrlrl}
\hline Variable & $N$ & $\begin{array}{l}\text { Mean rank } \\
\text { difference }\end{array}$ & $U$ & Significance \\
\hline Refinement & 153 & 0.2 & 1544 & 0.984 \\
Edge straightness & 74 & 3.31 & 534 & 0.54 \\
Plan symmetry & 150 & 7.03 & 1416 & 0.460 \\
Profile symmetry & 68 & 11.79 & 338 & 0.02 \\
\hline
\end{tabular}


Table 13 Results of regression analyses determining the relationship between flake scar density, percent of aberrant terminations, and invasiveness of flaking against each of the test variables for bifaces from Olduvai Gorge, Olorgesailie, Kariandusi, and Isinya

\begin{tabular}{llllll}
\hline Variable & df & $R$ square & $F$ & Significance & Significant variable \\
\hline Refinement & 257 & 0.043 & 3.773 & 0.011 & Invasiveness \\
Edge straightness & 181 & 0.064 & 3.933 & 0.01 & Invasiveness \\
Plan symmetry & 251 & 0.021 & 1.763 & 0.155 & None \\
Profile symmetry & 164 & 0.04 & 2.242 & 0.085 & Invasiveness \\
\hline
\end{tabular}

Gorge and the subtle influence of invasiveness on refinement and edge straightness may reflect the use of new techniques by the Olduvai knappers.

Achieving high levels of knapping skill takes practice and time. Hominin life history is thought to have expanded over the course of the Acheulean (Robson and Wood 2008), with the emergence of adolescence as an additional life history stage not shared with other great apes (Thompson et al. 2003). This added time to practice knapping when individuals would have been strong enough to flake effectively, but still with high levels of brain plasticity in comparison to adults (Spear 2013), may have allowed new knapping techniques to become part of the hominin behavioural repertoire (Hopkinson et al. 2013).

Over relatively short timescales, variation in skill does not appear progressive and a random walk model is more appropriate. However, on timescales of the order of hundreds of thousands of years, where confounding factors such as rock type are held relatively constant,

Table 14 Results of the univariate general linear models. Only significant individual variables and interactions are shown. Independent variables with partial eta squared values of more than 0.1 are highlighted in bold

\begin{tabular}{|c|c|c|c|c|}
\hline & Variable & $F$ & Significance & Partial eta squared \\
\hline \multirow[t]{6}{*}{ Refinement $(\mathrm{df}=232)$} & Corrected model & 5.936 & $<0.001$ & 0.585 \\
\hline & Assemblage & 4.819 & $<0.001$ & 0.157 \\
\hline & Material & 2.98 & 0.033 & 0.047 \\
\hline & Blank & 4.333 & 0.015 & 0.046 \\
\hline & Scar density & 9.255 & 0.003 & 0.049 \\
\hline & Material-blank & 3.393 & 0.019 & 0.051 \\
\hline \multirow[t]{8}{*}{ Edge straightness $(\mathrm{df}=155)$} & Corrected model & 11.567 & $<0.001$ & 0.8 \\
\hline & Assemblage & 10.657 & $<0.001$ & 0.404 \\
\hline & Material & 2.893 & 0.039 & 0.073 \\
\hline & Scar density & 11.645 & 0.001 & 0.096 \\
\hline & Invasiveness & 4.906 & 0.029 & 0.043 \\
\hline & Assemblage-material & 4.492 & $<0.001$ & 0.222 \\
\hline & Material-blank & 5.097 & 0.002 & 0.122 \\
\hline & Assemblage-material-blank & 3.257 & 0.042 & 0.056 \\
\hline \multirow[t]{4}{*}{ Plan symmetry $(\mathrm{df}=225)$} & Corrected model & 2.698 & $<0.001$ & 0.399 \\
\hline & Assemblage & 4.803 & $<0.001$ & 0.161 \\
\hline & Blank & 3.668 & 0.027 & 0.039 \\
\hline & Material-blank & 3.375 & 0.02 & 0.055 \\
\hline \multirow[t]{4}{*}{ Profile symmetry $(\mathrm{df}=141)$} & Corrected model & 2.533 & $<0.001$ & 0.486 \\
\hline & Blank & 10.3 & $<0.001$ & 0.172 \\
\hline & Assemblage-material & 2.186 & 0.042 & 0.134 \\
\hline & Assemblage-blank & 2.27 & 0.023 & 0.171 \\
\hline
\end{tabular}


such as between the major beds at Olduvai, there is a discernible increase in knapping skill. Elsewhere in the Acheulean world, quantitative studies are picking up long-term trends in biface knapping that point to increasing skill levels (Chazan 2015; Gallotti and Mussi 2017; Gilead 1977; Grosman et al. 2011a; Iovita et al. 2017; Li et al. 2016; Schick and Toth 2017; Shipton 2013; Shipton 2016). Acheulean biface morphology is subject to many different influences resulting in a high degree of variation between assemblages, but, over the course of hundreds of thousands of years, there are perceptible signatures of increasing knapping skill. These may be related to the expanding hominin brain, the invention of knapping techniques, the extension of life history, or some combination of the three.

\begin{abstract}
Acknowledgements This research was funded by the University of Queensland. I thank Hélène Roche, Rick Potts, Purity Kiura, Ian Carroll, Zena McGreevy, the National Museums of Kenya, the Institute of Archaeology (London), the Cambridge Museum of Archaeology and Anthropology, the Pitt Rivers Museum, and the British Museum for access to the collections. Nadine Roseboom's assistance with collecting the data is gratefully acknowledged. The comments of Michael Chazan, Ignacio de la Torre, and anonymous reviewers were used to improve this manuscript.
\end{abstract}

\section{Compliance with Ethical Standards}

Conflict of Interest The author declares that he has no conflict of interest.

\section{Appendix A1}

A list of biface specimens scanned from Olduvai Gorge: 441934 12-14; 1934 12-14 35; 1934 12-14 45; 19314121471934 12-14; 1931-3153 1934 12-14 34; 51/963 LP717; 1931-4122 34.1105A; 1931-2769 34.1105D; x95; 431934 12-14 43;124; 1931-4177; 51/972 LP726; 34-1103A; 34-1103B; 34.1104A; 1931-3247 14; 1931-3131 1934 12-14 35; 1931-4128 381934 1214 38; 1931-4201 1934 12-14 42; 1931-3570 1934 1214 53; 1931-3455 261934 12-14; 51/966 LP720; 19313400 34.1101A; 1931-3405 46; 51/969 LP723 F; 19312378 34.1104C; 233; 51/968 LP722; 51/964 LP718; 1931-A136 21; 1931-2386 371934 12-14 37; 193134911937 2-8 2; 1931-3560 551934 12-14; 51/986 LP740; 1931-1358; 1931-3260 1934 12-14 52; 19313505 Z21462; 1934 12-14 50; 1931-2112 1934 12-14 54; 1934 12-14 51; 51/970 LP724 1931-3532; 51/971 LP725 1931-3541; 57.58 7b; 1941 x9-24 7c 57-58;
1931-3274 561934 12-14 56; 1931-2373 1934 12-14 70; 1931-3940 1934 12-14 63; 1931-3579 671934 1214; 1931-3580 1934 12-14 72; 1931-3784 1934 12-14 87; 51/1000 LP754 1931-2818; 1931-2803 1934 12-14 78; 1931-3332 1934 12-14 80; 1931-3674 1934 12-14 79; 1931-2382 1934 12-14 95; 1931-3593 34.1109C; 1931 12-14 60; 1931-2651 1934 12-14 75; 1931-2972 1934 12-14 82; 19321934 12-14 85; 1931-3165 1934 12-14 88; 1932821934 12-14 89; 1934 12-14 83; 1932 4-5 3; 51/997 LP751; 51/1002 LP756 1931-2855; 51/ 1001 LP755 1931-2860; 51/990 LP744 1931-3021; 1931-3972 34.1111; 1931-3298 1934 12-14 62; 1934 12-14 94; 1931-3A1 1932 4-5 1; 1934 12-14 58; 19312294651934 12-14; 1931-2293 691934 12-14; 1931 27871934 12-14 91; 1931-3655 1934 12-14 93; 51/ 1005 LP759; 51/1003 LP757; 1931-2826 1932 4-5 2; 1931-3035 1934 12-14 59; 1931-2996 1934 12-14 81; 1931-3951 1934 12-14 86; 51/987 LP741; 51/989 LP743 1931-2031; 34.1108D; 1931-3312 1934 12-14 57; 1931-3308 611934 12-14; 1931-3440 1934 12-14 64; 1931-3195 1934 12-14 68; 1931-2677 1934 12-14 74; 1931-3336 1934 12-14; 1934 12-14 71; 51/991 LP745; 51/1004 LP758; 51/992 LP746 1931-3319; 1931-3862 34.1104B; 51/973 LP727.

\section{Appendix A2}

A list of biface specimens scanned from Olorgesailie. Locality CL1-1: 30; 65; 74; 89; 102; 106; $112 ; 123 ; 142$; $160 ; 172 ; 173 ; 193 ; 196 ; 226 ; 233 ; 241 ; 244 ; 251 ; 256$; $261 ; 263 ; 279 ; 290 ; 301 ; 318 ; 329 ; 349 ; 418 ; 438$. Locality I3: 21 cleavers; 21 handaxes; $23 ; 107 ; 109$; $115 ; 117 ; 163 ; 182 ; 184 ; 197 ; 204 ; 241 ; 289 ; 302 ; 305$; $315 ; 343 ; 40 ; 41 ; 502 ; 74 ; 94 ; 96$. Locality DE/89B: $1801 ; 2008 ; 2023 ; 2162 ; 2167 ; 2357 ; 3078 ; 3111$; 31,$723 ; 3277 ; 3296 ; 3331 ; 3530 ; 4067$. Locality H9: 1343; 1532; 353-1. Locality DE/89C 1010; 922; 951; 8101; L96; 982. Locality Meng: x402 248; x402 251; x402 253; x402 256; x402 265; x402 266; x402 276. Locality 10: 14; 29; 318 x4023; 406; LA25; x402 2664.

\section{Appendix A3}

A list of biface specimens scanned from Kariandusi (specimens without a unique number written them were assigned a number from the database of this study with the prefix id): 1401 id883; 1401 id884; 1401 id885; 1401 id886; 1929-864 X51 54; 1931 X5a3; 1931-3002 x51; 1931-3874 x5a3 55; 1931-3881 x5a3; 1931-3882 
x53a; 1931-3887 x5a3 58; 1931-3889 x5a3 59; 1931$3894 \times 5 \mathrm{a} 3 ; 1931-3895 \times 5 \mathrm{a} 3 ; 1931-3897 \times 5 \mathrm{a} 364 ; 1931-$ 3902 x5a3; 1931-397; 1931-400; 1931-412; 1931-445; 1931-446; 1931-458; 1931-460; 1931-461; 1931-466; 1931-481; 1931-498; 1931-5067 x5a3 47; 1931-5068 x5a3; 1931-5069 x5a3; 1931-5071 x51 4; 1931-5072 x51 23; 1931-526; 1931-532; 1931-544; 1931-567; 1931-582 x51; 1931-586 x51 37; 1931-613 X51 15; 1931-656 x51; 1931-680; 1931-683; 1931-685 x51; 1931-689 x51; 1931-709 x51; 1931-809; 1931-825; 1931-831; 1931-843; 1931-847; 1931-876; 1931-897; 1931-900; 1931-932; 1931-941; 1931-944; 1931-951; 1947-2-32; 1947-2-73; GKR 1931-570 X51; KR X53 3; M30 1929 X5a3; M33 1929 x5a4 42; M47 1929 x5a4 63; x51 1931-652; x53 id 877; x53 id 880; X53 id 878; x5a1 obsidian; x5a1 trachyte; x5a3 x5a5 10; x5a5 21; x5a5 30; x5a5 6; x5a5 8; x5a5 id887; x5a5 id888

\section{Appendix A4}

A list of biface specimens scanned from Isinya: $87 \mathrm{NA}$ BCD255; Z165-Z166 V sommet?; B2 G7 V 19; Y170 102; Y768 V 25; XI68 VI 36; Y1 65 V 13; Y168 VI 69; Y168 VI 62; Y168 VI 64; Y168 VI 87; Z172 V 23; A266 VI 51; A266 VI 89; B262 VI 13; C2 70 VI 1; C264 VI 67; D263 VI 64; Zn66 VI VIsen7 47; G264 V 11; G266 VI 21; G268 13; C264 VI6 115; F268 VI 38; F268 VI 41; G265 VI 72; H261 VI 29; G252 107; A262 VI 35; B260 VI 49; C263 VI 75; D259 VI 40; H2 61W 31; G253 104.

Open Access This article is distributed under the terms of the Creative Commons Attribution 4.0 International License (http:// creativecommons.org/licenses/by/4.0/), which permits unrestricted use, distribution, and reproduction in any medium, provided you give appropriate credit to the original author(s) and the source, provide a link to the Creative Commons license, and indicate if changes were made.

\section{References}

Benito-Calvo, A., Barfod, D. N., McHenry, L. J., \& de la Torre, I. (2014). The geology and chronology of the Acheulean deposits in the Mieso area (east-central Ethiopia). Journal of Human Evolution, 76, 26-38.

Beyene, Y., Katoh, S., WoldeGabriel, G., Hart, W. K., Uto, K., Sudo, M., Kondo, M., Hyodo, M., Renne, P. R., Suwa, G., \& Asfaw, B. (2013). The characteristics and chronology of the earliest Acheulean at Konso, Ethiopia. PNAS, 110, 1584-1591.

Bradley, B., \& Sampson, C. G. (1986). Analysis by replication of two Acheulian artefact assemblages. In G. Bailey \& P. Callow (Eds.), Stone Age prehistory: Studies in honour of Charles McBurney (pp. 29-45). Cambridge: Cambridge University Press.

Bruner, E. (2010). Morphological differences in the parietal lobes within the human genus. Current Anthropology, 51, S77-S88.

Bruner, E., \& Holloway, R. L. (2010). A bivariate approach to the widening of the frontal lobes in the genus Homo. Journal of Human Evolution, 58, 138-146.

Callahan, E. (1979). The basics of biface knapping in the eastern fluted point tradition: A manual for flintknappers and lithic analysts. Bethlehem: Eastern States Archeological Federation.

Chazan, M. (2015). Technological trends in the Acheulean of Wonderwerk Cave, South Africa. African Archaeological Review, 32, 701-728.

Clark, J. D. (1994). The Acheulian industrial complex in Africa and elsewhere. In R. S. Corruccini, R. L. Ciochon, \& F. C. Howell (Eds.), Integrative paths to the past: Paleoanthropological advances in honor of F. Clark Howell (pp. 451-469). Englewood Cliffs: Prentice-Hall.

Clark, J. D. (1999). Cultural continuity and change in hominid behaviour in Africa during the Middle to Upper Pleistocene transition. In H. Ullrich (Ed.), Hominid evolution: Lifestyles and survival strategies (pp. 277-291). Gelsenkirchen: Edition Archaea.

Clark, J. (2001). Variability in primary and secondary technologies of the later Acheulian in Africa. In S. Milliken \& J. Cook (Eds.), A very remote period indeed: Papers on the Palaeolithic presented to Derek Roe (pp. 1-18). Oxford: Oxbow Books.

Claud, É., Deschamps, M., Colonge, D., Mourre, V., \& Thiébaut, C. (2015). Experimental and functional analysis of late Middle Paleolithic flake cleavers from southwestern Europe (France and Spain). Journal of Archaeological Science, 62, 105-127.

Darmark, K. (2010). Measuring skill in the production of bifacial pressure flaked points: A multivariate approach using the flip-test. Journal of Archaeological Science, 37, 2308-2315.

de la Torre, I., Mora, R., Arroyo, A., \& Benito-Calvo, A. (2014). Acheulean technological behaviour in the Middle Pleistocene landscape of Mieso (east-central Ethiopia). Journal of Human Evolution, 76, 1-25.

de Mortillet, G. (1873). Classification des diverses périodes de l'âge de la pierre, par Gabriel de Mortillet: Extrait du compte rendu du Congrès International d'Anthropologie et d'Archéologie Préhistoriques. 6me session, Brux: 1872. Weizenbach: Typ.

Diez-Martín, F., Sánchez Yustos, P., Uribelarrea, D., Baquedano, E., Mark, D. F., Mabulla, A., Fraile, C., Duque, J., Díaz, I., Pérez-González, A., Yravedra, J., Egeland, C. P., Organista, E., \& Domínguez-Rodrigo, M. (2014). The origin of the Acheulean: The 1.7 million-year-old site of FLK West, Olduvai Gorge (Tanzania). Scientific Reports, 5, 17839-17839.

Domínguez-Rodrigo, M., Serrallonga, J., Juan-Tresserras, J., Alcala, L., \& Luque, L. (2001). Woodworking activities by 
early humans: A plant residue analysis on Acheulian stone tools from Peninj (Tanzania). Journal of Human Evolution, 40, 289-299.

Durkee, H., \& Brown, F. H. (2014). Correlation of volcanic ash layers between the Early Pleistocene Acheulean sites of Isinya, Kariandusi, and Olorgesailie, Kenya. Journal of Archaeological Science, 49, 510-517.

Edwards, S. W. (2001). A modern knapper's assessment of the technical skills of the late Acheulean biface workers at Kalambo Falls. In J. D. Clark (Ed.), Kalambo Falls prehistoric site (Vol. 3, pp. 605-611). Cambridge: Cambridge University Press.

Eren, M. I., Roos, C. I., Story, B. A., von Cramon-Taubadel, N., \& Lycett, S. J. (2014). The role of raw material differences in stone tool shape variation: An experimental assessment. Journal of Archaeological Science, 49, 472-487.

Faisal, A., Stout, D., Apel, J., \& Bradley, B. (2010). The manipulative complexity of Lower Paleolithic stone toolmaking. PLoS One, 5, e13718.

Gaillard, C., Raju, D., Misra, V., \& Rajaguru, S. (1986). Handaxe assemblages from the Didwana region, Thar Desert, India: A metrical analysis. Proceedings of the Prehistoric Society, 52, 189-214

Galán, A., \& Domínguez-Rodrigo, M. (2014). Testing the efficiency of simple flakes, retouched flakes and small handaxes during butchery. Archaeometry, 56, 1054-1074.

Gallotti, R., \& Mussi, M. (2017). Two Acheuleans, two humankinds: From 1.5 to 0.85 Ma at Melka Kunture (Upper Awash, Ethiopian highlands). Journal of Anthropological Sciences, 95, 1-46.

Geribàs, N., Mosquera, M., \& Vergès, J. M. (2010). What novice knappers have to learn to become expert stone toolmakers. Journal of Archaeological Science, 37, 2857-2870.

Gilead, D. (1970). Handaxe industries in Israel and the Near East. World Archaeology, 2, 1-11.

Gilead, D. (1977). Some metrical studies of Acheulian assemblages in Israel. Eretz Israel, 13, 38-49.

Goren-Inbar, N., Lister, A., Werker, E., \& Chech, M. (1994). A butchered elephant skull and associated artifacts from the Acheulian site of Gesher Benot Ya'aqov, Israel. Paléorient, 20, 99-112.

Gowlett, J. (2015). Variability in an early hominin percussive tradition: The Acheulean versus cultural variation in modern chimpanzee artefacts. Philosophical Transactions of the Royal Society, Biological Sciences, 370, 20140358.

Grosman, L., Goldsmith, Y., \& Smilansky, U. (2011a). Morphological analysis of Nahal Zihor handaxes: A chronological perspective. PaleoAnthropology, 2011, 203-215.

Grosman, L., Sharon, G., Goldman-Neuman, T., Smikt, O., \& Smilansky, U. (2011b). Studying post depositional damage on Acheulian bifaces using 3-D scanning. Journal of Human Evolution, 60, 398-406.

Hardaker, T., \& Dunn, S. (2005). The flip test-a new statistical measure for quantifying symmetry in stone tools. Antiquity, 79(306).

Hay, R. (1971). Geologic background of Beds I and II: Stratigraphic summary. In M. Leakey (Ed.), Olduvai Gorge: Excavations in Beds I and II 1960-1963 (Vol. 3, pp. 9-18). Cambridge: Cambridge University Press.
Hay, R. L. (1976). Geology of the Olduvai Gorge: A study of sedimentation in a semiarid basin. Berkeley: University of California Press.

Hayden, B., \& Villeneuve, S. (2009). Sex, symmetry and silliness in the bifacial world. Antiquity, 83, 1163-1170.

Hecht, E., Gutmanm, D. A., Khreisheh, N., Taylor, S. V., Kilner, J., Faisal, A. A., Bradley, B. A., Chaminade, T., \& Stout, D. (2015). Acquisition of Paleolithic toolmaking abilities involves structural remodeling to inferior frontoparietal regions. Brain Structure and Function, 220, 2315-2331.

Herzlinger, G., Goren-Inbar, N., \& Grosman, L. (2017). A new method for 3D geometric morphometric shape analysis: The case study of handaxe knapping skill. Journal of Archaeological Science: Reports, 14, 163-173.

Hodgson, D. (2010). Another side of symmetry: The Acheulean biface debate. Antiquity, 84, 325.

Hodgson, D. (2011). The first appearance of symmetry in the human lineage: Where perception meets art. Symmetry, 3, $37-53$.

Hodgson, D. (2015). The symmetry of Acheulean handaxes and cognitive evolution. Journal of Archaeological Science: Reports, 2, 204-208.

Hopkinson, T., Nowell, A., \& White, M. (2013). Life histories, metapopulation ecology, and innovation in the Acheulian. PaleoAnthropology, 2013, 61-76.

Iovita, R., Tuvi-Arad, I., Moncel, M.-H., Despriéem, J., Voinchet, P., \& Bahain, J.-J. (2017). High handaxe symmetry at the beginning of the European Acheulian: The data from la Noira (France) in context. PLoS One, 12, e 0177063.

Isaac, G. L. (1969). Studies of early culture in East Africa. World Archaeology, 1, 1-28.

Isaac, G. L. (1971). Early phases of human behaviour: Models in Lower Palaeolithic archaeology. In D. L. Clarke (Ed.), Models in archaeology (pp. 167-199). London: Routledge.

Isaac, G. L. (1972). Chronology and the tempo of cultural change during the Pleistocene. In W. W. Bishop \& J. A. Miller (Eds.), Calibration of hominoid evolution (pp. 381-430). Edinburgh: Scottish Academic Press.

Isaac, G. L., \& Isaac, B. (1977). Olorgesailie: Archeological studies of a Middle Pleistocene lake basin in Kenya. Chicago: University of Chicago Press.

Jones, P. R. (1979). Effects of raw materials on biface manufacture. Science, 204, 835-836.

Jones, P. R. (1980). Experimental butchery with modern stone tools and its relevance for Palaeolithic archaeology. World Archaeology, 12, 153-165.

Jones, P. R. (1994). Results of experimental work in relation to the stone industries of Olduvai Gorge. In M. D. Leakey \& D. Roe (Eds.), Olduvai Gorge - excavations in Beds III, IV and the Masek Beds (1968-71) (Vol. 5, pp. 254-298). Cambridge: Cambridge University Press.

Jordan, J. S. (2002). Deriving intentionality from artifacts. Behavioral and Brain Sciences, 25, 412-412.

Key, A. J., \& Lycett, S. J. (2017). Reassessing the production of handaxes versus flakes from a functional perspective. Archaeological and Anthropological Sciences, 9, 737-753.

Key, A., Dunmore, C. J., Hatala, K. G., \& Williams-Hatala, E. M. (2017). Flake morphology as a record of manual pressure during stone tool production. Journal of Archaeological Science: Reports, 12, 43-53. 
Kohn, M., \& Mithen, S. (1999). Handaxes: Products of sexual selection? Antiquity, 73, 518-526.

Leakey, L. S. B. (1951). Olduvai Gorge: A report on the evolution of the hand-axe culture in Beds I-IV. With chapters on the geology and fauna. Cambridge: Cambridge University Press.

Leakey, M. D. (1967). Preliminary survey of the cultural material from Beds I and II, Olduvai Gorge, Tanzania. In W. W. Bishop \& J. D. Clark (Eds.), Background to evolution in Africa (pp. 417-446). Chicago: University of Chicago Press.

Leakey, M. D. (1971). Olduvai Gorge, vol. 3, excavations in Beds I and II, 1960-1963. Cambridge: Cambridge University Press.

Leakey, L. S. B., Tobias, P. V., \& Leakey, M. D. (1965). Olduvai Gorge. 1. 1951-61, a preliminary report on the geology and fauna. Cambridge: Cambridge University Press.

Lepre, C. J., Roche, H., Kent, D. V., Harmand, S., Quinn, R. L., Brugal, J.-P., Texier, P.-J., Lenoble, A., \& Feibel, C. S. (2011). An earlier origin for the Acheulian. Nature, 477, $82-85$.

Li, H., Kuman, K., Leader, G. M., \& Couzens, R. (2016). Handaxes in South Africa: Two case studies in the early and later Acheulean. Quaternary International. https://doi. org/10.1016/j.quaint.2016.08.025.

Lorenzo, C., Pablos, A., Carretero, J. M., Huguet, R., Valverdú, J., Martinón-Torres, M., Arsuaga, J. L., Carbonell, E., \& Bermúdez de Castro, J. M. (2015). Early Pleistocene human hand phalanx from the Sima del Elefante (TE) cave site in Sierra de Atapuerca (Spain). Journal of Human Evolution, 78, 114-121.

Lycett, S. J., \& von Cramon-Taubadel, N. (2014). Toward a "quantitative genetic" approach to lithic variation. Journal of Archaeological Method and Theory, 22(2), $646-675$.

Machin, A. (2009). The role of the individual agent in Acheulean biface variability: A multi-factorial model. Journal of Social Archaeology, 9, 35-58.

Machin, A. J., Hosfield, R. T., \& Mithen, S. J. (2007). Why are some handaxes symmetrical? Testing the influence of handaxe morphology on butchery effectiveness. Journal of Archaeological Science, 34, 883-893.

Marshall, G., Gamble, C., Roe, D., \& Dupplaw, D. (2002). Acheulian biface database URL (consulted October 2003). http://ads.ahds.ac.uk/catalogue/specColl/bifaces/bf_query. cfm. York: Archeology Data Service.

McHenry, L. J. (2005). Phenocryst composition as a tool for correlating fresh and altered tephra, Bed I, Olduvai Gorge, Tanzania. Stratigraphy, 2, 101-115.

McHenry, L. J., Mollel, G. F., \& Swisher, C. C. (2008). Compositional and textural correlations between Olduvai Gorge Bed I tephra and volcanic sources in the Ngorongoro Volcanic Highlands, Tanzania. Quaternary International, 178, 306-319.

McKinney, C. (2001). The uranium-series age of wood from Kalambo Falls. In J. D. Clark (Ed.), Kalambo Falls prehistoric site (Vol. 3, pp. 665-674). Cambridge: Cambridge University Press.

McNabb, J. (2005). Hominins and the Early-Middle Pleistocene transition: Evolution, culture and climate in Africa and Europe. Geological Society, London, Special Publications, 247, 287-304.
McNabb, J. (2013). Pole to pole. Archaeology and adaptation in the Middle Pleistocene at opposite ends of the Acheulean world. Oxford Journal of Archaeology, 32, 123-146.

McNabb, J., \& Cole, J. (2015). The mirror cracked: Symmetry and refinement in the Acheulean handaxe. Journal of Archaeological Science: Reports, 3, 100-111.

McPherron, S. P. (2000). Handaxes as a measure of the mental capabilities of early hominids. Journal of Archaeological Science, 27, 655-663.

McPherron, S. P. (2006). What typology can tell us about Acheulian handaxe production. In N. Goren-Inbar \& G. Sharon (Eds.), Axe age: Acheulian tool-making from quarry to discard (pp. 267-285). London: Equinox.

Misra, V. (1978). The Acheulian industry of rock shelter IIIF-23 at Bhimbetka, Central India - a preliminary study. Australian Archaeology, 8, 63-106.

Mitchell, J. (1995). Studying biface utilisation at Boxgrove: Roe deer butchery with replica handaxes. Lithic Technology, 16, 64-69.

Moore, M. W., \& Perston, Y. (2016). Experimental insights into the cognitive significance of early stone tools. PLoS One, 11, e0158803.

Muller, A., Clarkson, C., \& Shipton, C. (2017). Measuring behavioural and cognitive complexity in lithic technology throughout human evolution. Journal of Anthropological Archaeology, 48, 166-180.

Newcomer, M. H. (1971). Some quantitative experiments in handaxe manufacture. World Archaeology, 3, 85-94.

Noll, M. P. (2000). Components of Acheulean lithic assemblage variability at Olorgesailie, Kenya. PhD dissertation, University of Illinois at Urbana-Champaign.

Nowell, A. (2002). Coincidental factors of handaxe morphology. Behavioral and Brain Sciences, 25, 413-414.

Owen, R. B., Potts, R., Behrensmeyer, A. K., \& Ditchfield, P. (2008). Diatomaceous sediments and environmental change in the Pleistocene Olorgesailie Formation, southern Kenya Rift Valley. Palaeogeography, Palaeoclimatology, Palaeoecology, 269, 17-37.

Paddayya, K. (2007). Evolution within the Acheulian in India: A case study from the Hunsgi and Baichbal valleys. Karnataka Bulletin of the Deccan College Research Institute, 66-67.

Petraglia, M. D., \& Shipton, C. (2008). Large cutting tool variation west and east of the Movius Line. Journal of Human Evolution, 55, 962-966.

Piperno, M., \& Tagliacozzo, A. (2001). The elephant butchery area at the Middle Pleistocene site of Notarchirico (Venosa, Basilicata, Italy). In G. Cavarretta, P. Gioia, M. Mussi, \& M. R. Palombo (Eds.), La terra degli elefanti (pp. 230-236). Rome: Consiglio Nazionale delle Ricerche.

Pitts, M. W., \& Roberts, M. (1997). Fairweather Eden: Life in Britain half a million years ago as revealed by the excavations at Boxgrove. London: Random House.

Pope, M., \& Roberts, M. (2005). Observations on the relationship between Palaeolithic individuals and artefact scatters at the Middle Pleistocene site of Boxgrove, UK. In C. S. Gamble \& M. Porr (Eds.), The hominid individual in context: Archaeological investigations of Lower and Middle Palaeolithic, landscapes, locales and artefacts (pp. 81-97). London: Routledge.

Potts, R., Behrensmeyer, A. K., \& Ditchfield, P. (1999). Paleolandscape variation and Early Pleistocene hominid 
activities: Members 1 and 7, Olorgesailie Formation, Kenya. Journal of Human Evolution, 37, 747-788.

Potts, R., Behrensmeyer, A.K., Deino, A., Ditchfield, P. \& Clark, J. (2004). Small mid-Pleistocene hominin associated with East African Acheulean technology. Science, 305, 75-78.

Rightmire, G. P. (2004). Brain size and encephalization in Early to Mid-Pleistocene Homo. American Journal of Physical Anthropology, 124, 109-123.

Roberts, M. B., \& Parfitt, S. A. (1999). Boxgrove: A Middle Pleistocene hominid site at Eartham Quarry, Boxgrove, West Sussex. London: English Heritage.

Robson, S. L., \& Wood, B. (2008). Hominin life history: Reconstruction and evolution. Journal of Anatomy, 212, 394- 425.

Roche, H., Brugal, J.-P., Lefèvre, D., Ploux, S., \& Texier, P.-J. (1988). Isenya: État des recherches sur un nouveau site acheuléen d'Afrique orientale. African Archaeological Review, 6, 27-55.

Roe, D. A. (1969). British Lower and Middle Paleolithic handaxe groups. Proceedings of the Prehistoric Society (New Series), $34,1-82$.

Roe, D. A. (1994). A metrical analysis of selected sets of handaxes and cleavers from Olduvai Gorge. In M. Leakey (Ed.), Olduvai Gorge-Excavations in Beds III, IV and the Masek Beds (1968-71) (Vol. 5, pp. 146-235). Cambridge: Cambridge University Press.

Roux, V., \& David, E. (2005). Planning abilities as a dynamic perceptual-motor skill: An actualist study of different levels of expertise involved in stone knapping. In V. Roux \& B. Bril (Eds.), Stone knapping: A uniquely hominin behaviour (pp. 91-108). Cambridge: McDonald Institute for Archaeological Research.

Ruff, C. B., Trinkaus, E., \& Holliday, T. W. (1997). Body mass and encephalization in Pleistocene Homo. Nature, 387, 173-176.

Ryan, W. B., Carbotte, S. M., Coplan, J. O., O'Hara, S., Melkonian, A., Arko, R., Weissel, R. A., Ferrini, V., Goodwillie, A., Nitsche, F., Bonczkowski, J., \& Zemsky, R. (2009). Global multi-resolution topography synthesis. Geochemistry, Geophysics, Geosystems, 10(3). https://doi. org/10.1029/2008GC002332.

Sahnouni, M., Semaw, S., \& Rogers, M. (2013). The African Acheulean: An archaeological summary. In P. Mitchell \& P. J. Lane (Eds.), The Oxford handbook of African archaeology. Oxford: Oxford University Press.

Saragusti, I., Sharon, I., Katzenelson, O., \& Avnir, D. (1998). Quantitative analysis of the symmetry of artefacts: Lower Paleolithic handaxes. Journal of Archaeological Science, 25, 817-825.

Saragusti, I., Karasik, A., Sharon, I., \& Smilansky, U. (2005). Quantitative analysis of shape attributes based on contours and section profiles in artifact analysis. Journal of Archaeological Science, 32, 841-853.

Schick, K., \& Clark, J. D. (2003). Biface technological development and variability in the Acheulean industrial complex in the Middle Awash region of the Afar Rift, Ethiopia. In M. Soressi \& H. L. Dibble (Eds.), Multiple approaches to the study of bifacial technologies (pp. 1-30). Philadelphia: University of Pennsylvania Museum of Archaeology and Anthropology.

Schick, K., \& Toth, N. (2017). Acheulean industries of the Early and Middle Pleistocene, Middle Awash, Ethiopia. L'Anthropologie, 121(5), 451-491.
Schoenemann, P. T. (2002). Putting meat on the bones: The necessity of empirical tests of hypotheses about cognitive evolution. Behavioral and Brain Sciences, 25, 416-417.

Sharon, G., \& Goren-Inbar, N. (1999). Soft percussor use at the Gesher Benot Ya'aqov Acheulian site? Mitekufat Haeven, 28, 55-79.

Shelley, P. H. (1990). Variation in lithic assemblages: An experiment. Journal of Field Archaeology, 17, 187-193.

Shipton, C. (2011). Taphonomy and behaviour at the Acheulean site of Kariandusi, Kenya. African Archaeological Review, $28,141-155$.

Shipton, C. (2013). A million years of hominin sociality and cognition: Acheulean bifaces in the Hunsgi-Baichbal Valley, India. BAR International Series. Oxford: Archaeopress.

Shipton, C. (2016). Hierarchical organization in the Acheulean to Middle Palaeolithic transition at Bhimbetka, India. Cambridge Archaeological Journal, 26, 601-618.

Shipton, C., \& Clarkson, C. (2015a). Flake scar density and handaxe reduction intensity. Journal of Archaeological Science: Reports, 2, 169-175.

Shipton, C., \& Clarkson, C. (2015b). Handaxe reduction and its influence on shape: An experimental test and archaeological case study. Journal of Archaeological Science: Reports, 3, 408-419.

Solodenko, N., Zupancich, A., Cesaro, S. N., Marder, O., Lemorini, C., \& Barkai, R. (2015). Fat residue and usewear found on Acheulian biface and scraper associated with butchered elephant remains at the site of Revadim, Israel. PLoS One, 10, e0118572.

Spear, L. P. (2013). Adolescent neurodevelopment. Journal of Adolescent Health, 52, S7-S13.

Stout, D. (2002). Skill and cognition in stone tool production: An ethnographic case study from Irian Jaya. Current Anthropology, 43, 693-722.

Stout, D., Toth, N., Schick, K., \& Chaminade, T. (2008). Neural correlates of Early Stone Age toolmaking: Technology, language and cognition in human evolution. Philosophical Transactions of the Royal Society: Biological Sciences, 363, 1939-1949.

Stout, D., Passingham, R., Frith, C., Apel, J., \& Chaminade, T. (2011). Technology, expertise and social cognition in human evolution. European Journal of Neuroscience, 33, 1328-1338.

Stout, D., Apel, J., Commander, J., \& Roberts, M. (2014). Late Acheulean technology and cognition at Boxgrove, UK. Journal of Archaeological Science, 41, 576-590.

Tamrat, E., Thouveny, N., Tai, M., \& Opdyke, N. (1995). Revised magnetostratigraphy of the Plio-Pleistocene sedimentary sequence of the Olduvai Formation (Tanzania). Palaeogeography, Palaeoclimatology, Palaeoecology, 114, 273-283.

Thompson, J. L., Krovitz, G. E., \& Nelson, A. J. (2003). Patterns of growth and development in the genus Homo. Cambridge: Cambridge University Press.

Tocheri, M. W., Orr, C. M., Jacofsky, M. C., \& Marzke, M. W. (2008). The evolutionary history of the hominin hand since the last common ancestor of Pan and Homo. Journal of Anatomy, 212, 544-562.

Toth, N., \& Schick, K. (2009). The importance of actualistic studies in Early Stone Age research: Some personal reflections. In K. Schick \& N. Toth (Eds.), The cutting edge: New 
approaches to the archaeology of human origins (pp. 267344). Gosport: Stone Age Institute Press.

Trauth, M. H., Maslin, M. A., Deino, A., \& Strecker, M. R. (2005). Late Cenozoic moisture history of East Africa. Science, 309, 2051-2053.

Tryon, C. A., \& McBrearty, S. (2006). Tephrostratigraphy of the Bedded Tuff Member (Kapthurin Formation, Kenya) and the nature of archaeological change in the later Middle Pleistocene. Quaternary Research, 65, 492-507.

Underhill, D. (2007). Subjectivity inherent in by-eye symmetry judgements and the large cutting tools at the Cave of Hearths, Limpopo Province, South Africa. Papers from the Institute of Archaeology, 18, 101-113.

Ward, C. V., Tocheri, M. W., Plavcan, J. M., Brown, F. H., \& Manthi, F. K. (2014). Early Pleistocene third metacarpal from Kenya and the evolution of modern human-like hand morphology. PNAS, 111, 121-124.

White, M. J. (1998). On the significance of Acheulean biface variability in southern Britain. Proceedings of the Prehistoric Society, 64, 15-44.
Williams, E. M., Gordon, A., \& Richmond, B. G. (2014). Biomechanical strategies for accuracy and force generation during stone tool production. Journal of Human Evolution, $72,52-63$.

Winton, V. (2005). An investigation of knapping-skill development in the manufacture of Palaeolithic handaxes. In V. Roux \& B. Bril (Eds.), Stone knapping: A uniquely hominin behaviour (pp. 109-116). Cambridge: McDonald Institute for Archaeological Research.

Wynn, T. (1995). Handaxe enigmas. World Archaeology, 27, 10-24.

Wynn, T. (2000). Symmetry and the evolution of the modular linguistic mind. In P. Carruthers \& A. Chamberlain (Eds.), Evolution and the human mind: Modularity, language and meta-cognition (pp. 113-139). Cambridge: Cambridge University Press.

Wynn, T. (2002). Archaeology and cognitive evolution. Behavioral and Brain Sciences, 25, 389-402. 